\title{
Genetic variation in the immunosuppression pathway genes and breast cancer susceptibility: a pooled analysis of 42,510 cases and 40,577 controls from the Breast Cancer Association Consortium
}

Jieping Lei ${ }^{1} \cdot$ Anja Rudolph ${ }^{1} \cdot$ Kirsten B. Moysich $^{2} \cdot$ Sabine Behrens $^{1} \cdot$ Ellen L. Goode $^{3} \cdot$ Manjeet K. Bolla $^{4}$. Joe Dennis $^{4} \cdot$ Alison M. Dunning ${ }^{5}$ Douglas F. Easton ${ }^{4,5} \cdot$ Qin Wang $^{4} \cdot$ Javier Benitez $^{6,7} \cdot$ John L. Hopper $^{8}$. Melissa C. Southey ${ }^{9}$ Marjanka K. Schmidt ${ }^{10}$ - Annegien Broeks ${ }^{10} \cdot$ Peter A. Fasching ${ }^{11,12} \cdot$ Lothar Haeberle $^{11}$. Julian Peto $^{13}$ - Isabel dos-Santos-Silva ${ }^{13}$ - Elinor J. Sawyer ${ }^{14}$ - Ian Tomlinson ${ }^{15}$ - Barbara Burwinkel $^{16,17}$.


Sune F. Nielsen ${ }^{22} \cdot$ Børge G. Nordestgaard ${ }^{22,23}$ - Anna González-Neira ${ }^{6}$ - Primitiva Menéndez ${ }^{25}$ • Hoda Anton-Culver ${ }^{26} \cdot$ Susan L. Neuhausen ${ }^{27} \cdot$ Hermann Brenner $^{28,29,30} \cdot$ Volker Arndt $^{28} \cdot$ Alfons Meindl $^{31}$. Rita K. Schmutzler ${ }^{32,33,34}$ - Hiltrud Brauch ${ }^{30,35,36}$ - Ute Hamann ${ }^{37}$ - Heli Nevanlinna ${ }^{38}$ - Rainer Fagerholm ${ }^{38}$. Thilo Dörk ${ }^{39}$ - Natalia V. Bogdanova ${ }^{40}$ - Arto Mannermaa ${ }^{41,42,43} \cdot$ Jaana M. Hartikainen $^{41,42,43}$. Australian Ovarian Study Group ${ }^{44} \cdot$ kConFab Investigators $^{45} \cdot$ Laurien Van Dijck $^{46} \cdot$ Ann Smeets $^{47}$. Dieter Flesch-Janys $^{48,49} \cdot$ Ursula Eilber $^{1} \cdot$ Paolo Radice $^{50} \cdot$ Paolo Peterlongo $^{51} \cdot$ Fergus J. Couch $^{52}$. Emily Hallberg ${ }^{3}$ Graham G. Giles ${ }^{8,53} \cdot$ Roger L. Milne ${ }^{8,53} \cdot$ Christopher A. Haiman $^{54} \cdot$ Fredrick Schumacher $^{54}$. Jacques Simard $^{55}$ - Mark S. Goldberg ${ }^{56,57}$ - Vessela Kristensen ${ }^{58,59,60}$ • Anne-Lise Borresen-Dale ${ }^{58,59}$. Wei Zheng ${ }^{61}$ - Alicia Beeghly-Fadiel ${ }^{61}$ - Robert Winqvist ${ }^{62,63} \cdot$ Mervi Grip $^{64}$ - Irene L. Andrulis ${ }^{65,66}$. Gord Glendon $^{65} \cdot$ Montserrat García-Closas $^{67,68} \cdot$ Jonine Figueroa $^{68} \cdot$ Kamila Czene $^{69} \cdot$ Judith S. Brand $^{69}$. Hatef Darabi $^{69} \cdot$ Mikael Eriksson $^{69} \cdot$ Per Hall $^{69} \cdot{\text { Jingmei } \mathrm{Li}^{69} \cdot \text { Angela Cox }^{70} \cdot \text { Simon S. Cross }}^{71}$. Paul D. P. Pharoah ${ }^{4,5} \cdot$ Mitul Shah $^{5} \cdot$ Maria Kabisch $^{37}$ - Diana Torres ${ }^{37,72} \cdot$ Anna Jakubowska $^{73}$. Jan Lubinski ${ }^{73} \cdot$ Foluso Ademuyiwa $^{74}$ - Christine B. Ambrosone ${ }^{74} \cdot$ Anthony Swerdlow $^{75,76} \cdot$ Michael Jones $^{75}$. Jenny Chang-Claude ${ }^{1,77}$

Abstract Immunosuppression plays a pivotal role in assisting tumors to evade immune destruction and promoting tumor development. We hypothesized that genetic variation in the immunosuppression pathway genes may be implicated in breast cancer tumorigenesis. We included 42,510 female breast cancer cases and 40,577 controls of European ancestry from 37 studies in the Breast Cancer
Association Consortium (2015) with available genotype data for 3595 single nucleotide polymorphisms (SNPs) in 133 candidate genes. Associations between genotyped SNPs and overall breast cancer risk, and secondarily according to estrogen receptor (ER) status, were assessed using multiple logistic regression models. Gene-level associations were assessed based on principal component

Jieping Lei and Anja Rudolph share the first authorship.

Electronic supplementary material The online version of this article (doi:10.1007/s00439-015-1616-8) contains supplementary material, which is available to authorized users.

Jenny Chang-Claude

j.chang-claude@dkfz-heidelberg.de

1 Division of Cancer Epidemiology, German Cancer Research Center (DKFZ), Im Neuenheimer Feld 581,

69120 Heidelberg, Germany
Department of Cancer Prevention and Control, Roswell Park Cancer Institute, Buffalo, NY, USA

3 Department of Health Sciences Research, Mayo Clinic, Rochester, MN, USA 
analysis. Gene expression analyses were conducted using RNA sequencing level 3 data from The Cancer Genome Atlas for 989 breast tumor samples and 113 matched normal tissue samples. SNP rs1905339 (A>G) in the STAT3 region was associated with an increased breast cancer risk (per allele odds ratio $1.05,95 \%$ confidence interval $1.03-1.08 ; p$ value $\left.=1.4 \times 10^{-6}\right)$. The association did not differ significantly by ER status. On the gene level, in addition to TGFBR2 and CCND1, IL5 and GM-CSF showed the strongest associations with overall breast cancer risk $\left(p\right.$ value $=1.0 \times 10^{-3}$ and $7.0 \times 10^{-3}$, respectively). Furthermore, STAT3 and IL5 but not GM-CSF were differentially expressed between breast tumor tissue and normal tissue $\left(p\right.$ value $=2.5 \times 10^{-3}, 4.5 \times 10^{-4}$ and 0.63 , respectively). Our data provide evidence that the immunosuppression pathway genes STAT3, IL5, and GMCSF may be novel susceptibility loci for breast cancer in women of European ancestry.

\section{Abbreviations}

BCAC Breast Cancer Association Consortium

CCND1 Cyclin D1

CI Confidence interval

COGS Collaborative Oncological Gene-Environment Study

4 Centre for Cancer Genetic Epidemiology, Department of Public Health and Primary Care, University of Cambridge, Cambridge, UK

5 Centre for Cancer Genetic Epidemiology, Department of Oncology, University of Cambridge, Cambridge, UK

6 Human Cancer Genetics Program, Spanish National Cancer Research Centre, Madrid, Spain

7 Centro de Investigación en Red de Enfermedades Raras, Valencia, Spain

8 Centre for Epidemiology and Biostatistics, Melbourne School of Population and Global Health, The University of Melbourne, Melbourne, Australia

9 Department of Pathology, The University of Melbourne, Melbourne, Australia

10 Netherlands Cancer Institute, Antoni van Leeuwenhoek Hospital, Amsterdam, The Netherlands

11 Department of Gynaecology and Obstetrics, University Hospital Erlangen, Friedrich-Alexander University ErlangenNuremberg, Comprehensive Cancer Center Erlangen-EMN, Erlangen, Germany

12 David Geffen School of Medicine, Department of Medicine Division of Hematology and Oncology, University of California at Los Angeles, Los Angeles, CA, USA

13 Department of Non-Communicable Disease Epidemiology, London School of Hygiene and Tropical Medicine, London, UK
DNA Deoxyribonucleic acid

GM-CSF Granulocyte-macrophage colony stimulating factor

EM Estimation maximization

ENCODE Encyclopedia of DNA elements

eQTL Expression quantitative trait loci

ER Estrogen receptor

GWAS Genome-wide association study

HWE Hardy-Weinberg equilibrium

IL5 Interleukin 5

LD Linkage disequilibrium

MAF Minor allele frequency

MDSCs Myeloid-derived suppressor cells

OR

PCs Principal components

PTRF Polymerase I and transcript release factor

QQ Quantile-quantile

RSEM RNA-Seq by expectation-maximization

SD Standard deviation

SNPs Single nucleotide polymorphisms

STAT3 Signal transducer and activator of transcription 3

TCGA The Cancer Genome Atlas

TGFBR2 Transforming growth factor beta receptor II Treg cells Regulatory $\mathrm{T}$ cells

TUBG2 Tubulin, gamma 2

14 Research Oncology, Guy's Hospital, King's College London, London, UK

15 Wellcome Trust Centre for Human Genetics and Oxford NIHR Biomedical Research Centre, University of Oxford, Oxford, UK

16 Department of Obstetrics and Gynecology, University of Heidelberg, Heidelberg, Germany

17 Molecular Epidemiology Group, German Cancer Research Center (DKFZ), Heidelberg, Germany

18 National Center for Tumor Diseases, University of Heidelberg, Heidelberg, Germany

19 Environmental Epidemiology of Cancer, Center for Research in Epidemiology and Population Health, INSERM, Villejuif, France

20 University Paris-Sud, Villejuif, France

21 Copenhagen General Population Study, Herlev Hospital, Copenhagen University Hospital, Herlev, Denmark

22 Department of Clinical Biochemistry, Herlev Hospital, Copenhagen University Hospital, Herlev, Denmark

23 Faculty of Health and Medical Sciences, University of Copenhagen, Copenhagen, Denmark

24 Department of Breast Surgery, Herlev Hospital, Copenhagen University Hospital, Herlev, Denmark 


\section{Introduction}

Breast cancer is the most frequent cancer among women and the second leading cause of cancer-related death after lung cancer in Europe. In addition to genetic variants with high and moderate penetrance, more than 90 common germline genetic variants contributing to breast cancer risk have been identified, comprising about $37 \%$ of the familial relative risk of the disease (Michailidou et al. 2013, 2015). This suggests that a substantial portion of inherited variation has not yet been identified. In addition, most of the known common susceptibility variants reside in non-coding regions and result in subtle regulation of gene expression. The biological mechanisms through which genetic variants exert their functions are still not entirely understood.

The ability to evade immune destruction has been increasingly recognized as a key hallmark of tumors (Hanahan and Weinberg 2011). Tumor cells may secrete immunosuppressive factors like TGF- $\beta$ which hampers infiltrating cytotoxic $\mathrm{T}$ lymphocytes and natural killer cells (Yang et al. 2010). Inflammatory cells like regulatory $\mathrm{T}$ cells (Treg cells), a subset of CD4+ T lymphocytes, as well as myeloid-derived suppressor cells (MDSCs) may be recruited into the tumor environment, which are actively immunosuppressive (Lindau et al. 2013; Reisfeld 2013). Higher prevalence of Treg cells has been found in various cancers (Chang et al. 2010; Michel et al. 2008; Watanabe

25 Servicio de Anatomía Patológica, Hospital Monte Naranco, Oviedo, Spain

26 Department of Epidemiology, University of California Irvine, Irvine, CA, USA

27 Beckman Research Institute of City of Hope, Duarte, CA, USA

28 Division of Clinical Epidemiology and Aging Research, German Cancer Research Center (DKFZ), Heidelberg, Germany

29 Division of Preventive Oncology, National Center for Tumor Diseases (NCT) and German Cancer Research Center (DKFZ), Heidelberg, Germany

30 German Cancer Consortium (DKTK), German Cancer Research Center (DKFZ), Heidelberg, Germany

31 Division of Gynaecology and Obstetrics, Technische Universität München, Munich, Germany

32 Center for Hereditary Breast and Ovarian Cancer, University Hospital of Cologne, Cologne, Germany

33 Center for Integrated Oncology (CIO), University Hospital of Cologne, Cologne, Germany

34 Center for Molecular Medicine Cologne (CMMC), University of Cologne, Cologne, Germany

35 Dr. Margarete Fischer-Bosch-Institute of Clinical Pharmacology Stuttgart, Stuttgart, Germany

36 University of Tübingen, Tübingen, Germany et al. 2002), including breast cancer (Bates et al. 2006). There is evidence that tumor infiltrating Treg cells endowed with immunosuppressive potential are associated with tumor progression and unfavorable prognosis, especially in estrogen receptor (ER)-negative breast cancer (Bates et al. 2006; Kim et al. 2013; Liu et al. 2012a). In addition, infiltrating MDSCs were also found in murine mammary tumor models (Aliper et al. 2014; Gad et al. 2014), but their relevance for breast cancer patients also in terms of prognosis is not well-understood. Furthermore, previous association studies have identified susceptibility alleles for breast cancer in two genes, TGFBR2 (transforming growth factor beta receptor II) (Michailidou et al. 2013) and CCND1 (cyclin D1) (French et al. 2013), which may be involved in immune regulation in cancer patients (Gabrilovich and Nagaraj 2009; Krieg and Boyman 2009), including those with breast cancer. We hypothesized that immunosuppression pathway genes, particularly those relevant to Treg cell and MDSC functions, may harbor further susceptibility variants associated with breast cancer tumorigenesis, with a possible differential association by ER status.

In this analysis, we investigated associations between breast cancer risk and single nucleotide polymorphisms (SNPs) in 133 candidate genes in the immunosuppression pathway in individual level data from the Breast Cancer Association Consortium (BCAC). We also assessed associations with breast cancer risk at the gene and pathway

37 Molecular Genetics of Breast Cancer, German Cancer Research Center (DKFZ), Heidelberg, Germany

38 Department of Obstetrics and Gynecology, Helsinki University Hospital, University of Helsinki, Helsinki, Finland

39 Gynaecology Research Unit, Hannover Medical School, Hannover, Germany

40 Department of Radiation Oncology, Hannover Medical School, Hannover, Germany

41 Cancer Center, Kuopio University Hospital, Kuopio, Finland

42 Institute of Clinical Medicine, Pathology and Forensic Medicine, University of Eastern Finland, Kuopio, Finland

43 Imaging Center, Department of Clinical Pathology, Kuopio University Hospital, Kuopio, Finland

44 Department of Genetics, QIMR Berghofer Medical Research Institute, Brisbane, QLD, Australia

45 The Peter MacCallum Cancer Centre, Melbourne, VIC, Australia

46 VIB Vesalius Research Center, Department of Oncology, University of Leuven, Leuven, Belgium

47 Multidisciplinary Breast Center, University Hospitals Leuven, University of Leuven, Leuven, Belgium

48 Institute for Medical Biometrics and Epidemiology, University Medical Center Hamburg-Eppendorf, Hamburg, Germany 
levels. Furthermore, we used publicly available datasets through the UCSC Genome Browser (2015) to examine the putative genetic susceptibility loci for potential regulatory function.

\section{Materials and methods}

\section{Study participants}

In this analysis, participants were restricted to 83,087 women of European ancestry from 37 case-control studies participating in BCAC, including 42,510 invasive breast cancer cases with stage I-III disease and 40,577 cancerfree controls. Of all breast cancer patients, 26,094 were known to have ER-positive disease and 6870 to have ERnegative disease. Details of included studies are summarized in Online Resource 1. All studies were approved by the relevant ethics committees and all participants gave informed consent (Michailidou et al. 2013).

\section{Candidate gene selection}

Candidate genes relevant to the Treg cell and MDSC pathways were identified through a comprehensive literature review in PubMed (DeNardo et al. 2010; DeNardo and Coussens 2007; Driessens et al. 2009; Gabrilovich and Nagaraj 2009; Krieg and Boyman 2009; Mills 2004;

49 Department of Cancer Epidemiology, Clinical Cancer Registry, University Medical Center Hamburg-Eppendorf, Hamburg, Germany

50 Unit of Molecular Bases of Genetic Risk and Genetic Testing, Department of Preventive and Predictive Medicine, Fondazione IRCCS (Istituto Di Ricovero e Cura a Carattere Scientifico) Istituto Nazionale dei Tumori (INT), Milan, Italy

51 IFOM, Fondazione Istituto FIRC (Italian Foundation of Cancer Research) di Oncologia Molecolare, Milan, Italy

52 Department of Laboratory Medicine and Pathology, Mayo Clinic, Rochester, MN, USA

53 Cancer Epidemiology Centre, Cancer Council Victoria, Melbourne, Australia

54 Department of Preventive Medicine, Keck School of Medicine, University of Southern California, Los Angeles, CA, USA

55 Genomics Center, Centre Hospitalier Universitaire de Québec Research Center, Laval University, Québec City, Canada

56 Department of Medicine, McGill University, Montreal, Canada

57 Division of Clinical Epidemiology, Royal Victoria Hospital, McGill University, Montreal, Canada

58 Department of Genetics, Institute for Cancer Research, Oslo University Hospital Radiumhospitalet, Oslo, Norway
Ostrand-Rosenberg 2008; Poschke et al. 2011; Sakaguchi et al. 2013; Sica et al. 2008; Wilczynski and Duechler 2010; Zitvogel et al. 2006; Zou 2005), using the search terms "immunosuppression"/"immunosuppressive", "regulatory T cells"/"Treg cells"/“FOXP3+ T cells", "myeloid derived suppressor cells"/“MDSCs", "immunosurveillance", and "tumor escape". The final candidate gene list included 133 immunosuppression-related genes (Online Resource 2). SNPs within $50 \mathrm{~kb}$ upstream and downstream of each gene were identified using HapMap CEU genotype data (2015) and dbSNP 126.

\section{SNP association analyses}

For the BCAC studies, genotyping was carried out using a custom Illumina iSelect array (iCOGS) designed for the Collaborative Oncological Gene-Environment Study (COGS) project (Michailidou et al. 2013). Of the 211,155 SNPs on the array, 4246 were located within $50 \mathrm{~kb}$ of the selected candidate genes. Centralized quality control of genotype data led to the exclusion of 651 SNPs. The exclusion criteria included a call rate less than $95 \%$ in all samples genotyped with iCOGS, minor allele frequency (MAF) less than 0.05 in all samples, evidence of deviation from Hardy-Weinberg equilibrium (HWE) at $p$ value $<10^{-7}$, and concordance in duplicate samples less than $98 \%$ (Michailidou et al. 2013). A total of 3595 SNPs passed all quality controls and was analyzed.

59 K.G. Jebsen Center for Breast Cancer Research, Institute of Clinical Medicine, Faculty of Medicine, University of Oslo, Oslo, Norway

60 Department of Clinical Molecular Biology, Oslo University Hospital, University of Oslo, Oslo, Norway

61 Division of Epidemiology, Department of Medicine, Vanderbilt-Ingram Cancer Center, Vanderbilt University School of Medicine, Nashville, TN, USA

62 Laboratory of Cancer Genetics and Tumor Biology, Department of Clinical Chemistry and Biocenter Oulu, University of Oulu, Oulu, Finland

63 Central Finland Hospital District, Jyväskylä Central Hospital, Jyväskylä, Finland

64 Department of Surgery, Oulu University Hospital, University of Oulu, Oulu, Finland

65 Lunenfeld-Tanenbaum Research Institute of Mount Sinai Hospital, Toronto, Canada

66 Department of Molecular Genetics, University of Toronto, Toronto, Canada

67 Division of Genetics and Epidemiology, The Institute of Cancer Research, London, UK

68 Division of Cancer Epidemiology and Genetics, National Cancer Institute, Rockville, MD, USA 
Per-allele associations with the number of minor alleles were assessed using multiple logistic regression models, adjusted for study, age (at diagnosis for cases or at recruitment for controls) and nine principal components (PCs) derived based on genotyped variants to account for European population substructure. We assessed the associations of SNPs with overall breast cancer risk as primary analyses, and then restricted to ER-positive (26,094 cases and 40,577 controls) and ER-negative subtypes (6870 cases and 40,577 controls) as secondary analyses. Differences in the associations between ER-positive and ER-negative diseases were assessed by case-only analyses, using ER status as the dependent variable. To determine the number of "independent" SNPs for adjustment of multiple testing, we applied the option "-indep-pairwise" in PLINK (Purcell et al. 2007). SNPs were pruned by linkage disequilibrium (LD) of $r^{2}<0.2$ for a window size of 50 SNPs and step size of 10 SNPs, yielding 689 "independent" SNPs. The significance threshold using Bonferroni correction corresponding to an alpha of $5 \%$ was $7.3 \times 10^{-5}$.

In order to identify more strongly associated variants, genotypes were imputed for SNPs at the locus for which strongest evidence of association was observed, via a twostage procedure involving SHAPEIT (Howie et al. 2012) and IMPUTEv2 (Howie et al. 2009), using the 1000 Genomes Project data as the reference panel (Abecasis et al. 2012). Details of the imputation procedure are described elsewhere (Michailidou et al. 2015). Models assessing associations with imputed SNPs were adjusted for 16 PCs based on 1000 Genome imputed data to further improve adjustment for population stratification. To determine independent signals within imputed SNPs at STAT3, we ran a stepwise forward multiple logistic regression model including the most significant genotyped SNP rs1905339 and all imputed SNPs, adjusted for study, age and 16 PCs.

69 Department of Medical Epidemiology and Biostatistics, Karolinska Institutet, Stockholm, Sweden

70 Sheffield Cancer Research Centre, Department of Oncology, University of Sheffield, Sheffield, UK

71 Academic Unit of Pathology, Department of Neuroscience, University of Sheffield, Sheffield, UK

72 Institute of Human Genetics, Pontificia Universidad Javeriana, Bogota, Colombia

73 Department of Genetics and Pathology, Pomeranian Medical University, Szczecin, Poland

74 Roswell Park Cancer Institute, Buffalo, NY, USA

75 Division of Genetics and Epidemiology, Institute of Cancer Research, London, UK

76 Division of Breast Cancer Research, Institute of Cancer Research, London, UK

77 University Cancer Center Hamburg (UCCH), University Medical Center Hamburg-Eppendorf, Hamburg, Germany
SNP association analyses and case-only analyses were all conducted using SAS 9.3 (Cary, NC, USA). All tests were two-sided.

For multiple associated SNPs located at the same gene, a Microsoft Excel SNP tool created by Chen et al. (2009) and the software HaploView 4.2 (Barrett et al. 2005) were used to examine LD structure between these SNPs. To be able to inspect LD structures and also for gene-level analyses, allele dosages of imputed SNPs had to be converted into the most probable genotypes. Therefore, we categorized the imputed allele dosage between $[0,0.5]$ as homozygote of the reference allele, the value between $[0.5,1.5]$ as heterozygote, and the value between $[1.5,2.0]$ as homozygote of the counted allele. The regional association plot was generated using the online tool LocusZoom (Pruim et al. 2010).

\section{Gene-level and pathway association analyses}

Gene-level associations were determined by a subset of PCs, which were derived from a linear combination of SNPs in each gene explaining $80 \%$ of the variation in the joint distribution of all relevant SNPs. Associations with derived PCs were assessed within a logistic regression framework (Biernacka et al. 2012), for overall breast cancer, ER-positive and ER-negative diseases, respectively. Pathway association of the immunosuppression pathway was assessed based on a global test of association by combining the gene-level $p$ values via the Gamma method (Biernacka et al. 2012). For gene-level associations, associations with $p$ value $<3.8 \times 10^{-4}$ (Bonferroni correction) were considered statistically significant. To gain empirical $p$ values for gene-level associations of TGFBR2 and $C C N D 1$ as well as for the pathway association, a Monte Carlo procedure was used with up to $1,000,000$ randomizations (Biernacka et al. 2012). An exact binomial test based on the results of the single SNPs association analyses was carried out to estimate enrichment of association in the immunosuppression pathway. Gene-level and pathway association analyses were carried out in $\mathrm{R}$ (version 3.1.1) using the package 'GSAgm' version 1.0.

\section{Haplotype analyses}

To follow up the interesting gene associations observed, haplotype analyses were performed to identify potential susceptibility variants. Haplotype frequencies were determined with the use of the estimation maximization (EM) algorithm (Long et al. 1995) implemented in PROC HAPLOTYPE in SAS 9.3 (Cary, NC, USA). Haplotypes with frequency more or equal than $1 \%$ were examined and the most common haplotype was used as the reference. Rare haplotypes with frequency less than $1 \%$ were grouped into one category. Haplotype-specific odds ratios 
(ORs) and $95 \%$ confidence intervals (CIs) were estimated within a multiple logistic regression framework, adjusted for the same covariates as in the single SNP association analyses. Global $p$ values for association of haplotypes with breast cancer risk were computed using a likelihood ratio test comparing models with and without haplotypes of the gene of interest.

\section{Gene expression analyses}

In order to examine whether potential causative genes influence RNA expression in breast tumor tissue, we downloaded RNA sequence level 3 data from The Cancer Genome Atlas (TCGA) (2015). We retrieved the RNA expression level as the form of RNA-Seq by expectation-maximization (RSEM) based on the IlluminaHiSeq_RNASeqV2 array. Gene expression differences in RNA levels between 989 invasive breast cancer tissues and 113 matched normal tissues for four genes of interest (STAT3, PTRF, IL5, and GM-CSF) were analyzed using a two-sided Wilcoxon-Mann-Whiney test. In addition, data from 183 breast tissues in the GTEx (V6) (2015) publically available online databases were evaluated to obtain information on whether the most interesting variants (rs1905339, rs8074296, rs146170568, chr17:40607850:I and rs77942990) were expression quantitative trait loci (eQTL) for any gene. Also, GTEx was queried to obtain information on whether the five variants were eQTL for STAT3 or PTRF.

\section{Functional annotation}

To investigate potential regulatory functions of interesting polymorphisms, we used the Encyclopedia of DNA Elements (ENCODE) database through the UCSC Genome Browser as well as Haploreg v4 (Ward and Kellis 2012).

\section{Results}

Selected characteristics of the study population are described in Table 1. The controls and breast cancer patients included in this study had comparable mean reference ages of 54.8 and 55.9 years and also the proportion of postmenopausal women was similar $(68 \%$ in controls and $69 \%$ in breast cancer patients). The proportion of women indicating a family history of breast cancer in first degree relatives was as expected greater in breast cancer patients $(25 \%)$ than in controls $(12 \%)$.

\section{Single SNP associations}

Excluding the known TGFBR2 and CCND1 breast cancer susceptibility loci, the quantile-quantile (QQ) plot for
Table 1 Characteristics of breast cancer cases and controls

\begin{tabular}{|c|c|c|c|c|}
\hline \multirow[t]{2}{*}{ Characteristic } & \multicolumn{2}{|c|}{ Controls } & \multicolumn{2}{|l|}{ Cases } \\
\hline & No. & $\%$ & No. & $\%$ \\
\hline Total number & 40,577 & & 42,510 & \\
\hline Age (mean, SD) & 54.8 & 12.0 & 55.9 & 11.6 \\
\hline \multicolumn{5}{|c|}{ Family history of breast cancer } \\
\hline No & 20,940 & 88 & 24,397 & 75 \\
\hline Yes & 2829 & 12 & 7971 & 25 \\
\hline Unknown/missing & 16,808 & & 10,142 & \\
\hline \multicolumn{5}{|l|}{ Menopausal status } \\
\hline Pre/perimenopausal & 9174 & 32 & 9296 & 31 \\
\hline Postmenopausal & 19,753 & 68 & 20,714 & 69 \\
\hline Unknown/missing & 11,650 & & 12,500 & \\
\hline \multicolumn{5}{|l|}{ Estrogen receptor status } \\
\hline Negative & & & 6870 & 21 \\
\hline Positive & & & 26,094 & 79 \\
\hline Unknown/missing & & & 9546 & \\
\hline \multicolumn{5}{|l|}{ Progesterone receptor status } \\
\hline Negative & & & 9299 & 33 \\
\hline Positive & & & 19,017 & 67 \\
\hline Unknown/missing & & & 14,194 & \\
\hline \multicolumn{5}{|l|}{ Triple-negative cancer } \\
\hline No & & & 13,675 & 84 \\
\hline Yes & & & 2600 & 16 \\
\hline Unknown/missing & & & 26,235 & \\
\hline \multicolumn{5}{|l|}{ Stage } \\
\hline 0 & & & 25 & 0.1 \\
\hline I & & & 12,044 & 50 \\
\hline II & & & 9711 & 40 \\
\hline III & & & 1975 & 8 \\
\hline IV & & & 496 & 2 \\
\hline Unknown/missing & & & 18,259 & \\
\hline \multicolumn{5}{|l|}{ Grade } \\
\hline Well differentiated & & & 6125 & 21 \\
\hline Moderately differentiated & & & 14,092 & 48 \\
\hline Poorly/un-differentiated & & & 8937 & 31 \\
\hline Unknown/missing & & & 13,356 & \\
\hline
\end{tabular}

$S D$ standard deviation

associations with overall breast cancer risk for the genotyped SNPs of the other candidate genes indicated deviation from expected $p$ values and thus evidence of further SNPs associated with breast cancer risk (Online Resource 3). Genetic associations with overall breast cancer risk for all assessed 3595 SNPs are summarized in Online Resource 4.

Four independent genotyped SNPs $\left(\mathrm{LD} r^{2}<0.3\right)$ were significantly associated with breast cancer risk at $p$ value $<7.3 \times 10^{-5}$, accounting for the multiple comparisons (Table 2). The four significant SNPs were located in or near TGFBR2, STAT3 and CCND1. Since TGFBR2 and 
Table 2 TGFBR2, CCND1 and STAT3 SNPs associated with overall breast cancer risk in women of European ancestry after Bonferroni correction $\left(p\right.$ value $\left.<7.3 \times 10^{-5}\right)$

\begin{tabular}{lclllllllll}
\hline SNP & Chr. & Position $^{\text {a }}$ & Gene & Minor allele & MAF cases & MAF controls & Cases & Controls & OR $\left(95 \%\right.$ CI ${ }^{\mathrm{b}}$ & $p$ value \\
\hline rs1431131 & 3 & $30,675,880$ & TGFBR2 & A & 0.37 & 0.36 & 42,508 & 40,574 & $1.06(1.04-1.08)$ & $2.6 \times 10^{-8}$ \\
rs11924422 & 3 & $30,677,484$ & TGFBR2 & C & 0.40 & 0.41 & 42,491 & 40,572 & $0.95(0.94-0.97)$ & $6.9 \times 10^{-6}$ \\
rs7177 & 11 & $69,466,115$ & CCND1 & C & 0.46 & 0.47 & 42,411 & 40,496 & $0.96(0.94-0.98)$ & $2.7 \times 10^{-5}$ \\
rs1905339 & 17 & $40,582,296$ & STAT3 & G & 0.34 & 0.33 & 42,504 & 40,576 & $1.05(1.03-1.08)$ & $1.4 \times 10^{-6}$ \\
\hline
\end{tabular}

SNP single nucleotide polymorphism, $C h r$. chromosome, $M A F$ minor allele frequency, $O R$ odds ratio, $C I$ confidence interval, $T G F B R 2$ transforming growth factor beta receptor II, CCND1 cyclin D1, STAT3 signal transducer and activator of transcription 3

${ }^{\text {a }}$ Build 37

${ }^{\mathrm{b}}$ OR per minor allele, adjusted for age, study and nine European principal components

Table 3 Associations with overall breast cancer risk for seven independent imputed SNPs at STAT3 in women of European ancestry

\begin{tabular}{|c|c|c|c|c|c|c|c|c|c|c|}
\hline \multirow[t]{2}{*}{ SNP } & \multirow[t]{2}{*}{ Chr. } & \multirow[t]{2}{*}{ Position $^{a}$} & \multirow{2}{*}{$\begin{array}{l}\text { Counted } \\
\text { allele }\end{array}$} & \multirow[t]{2}{*}{$\mathrm{AF}^{\mathrm{b}}$} & \multirow[t]{2}{*}{ Cases } & \multirow[t]{2}{*}{ Controls } & \multicolumn{2}{|c|}{ Single SNP analysis } & \multicolumn{2}{|c|}{ Conditional analysis $^{\mathrm{d}}$} \\
\hline & & & & & & & OR $(95 \% \mathrm{CI})^{\mathrm{c}}$ & $p$ value & OR $(95 \% \mathrm{CI})^{\mathrm{c}}$ & $p$ value \\
\hline rs8074296 & 17 & $40,583,421$ & $\mathrm{G}$ & 0.336 & 42,510 & 40,577 & $1.05(1.03-1.08)$ & $8.6 \times 10^{-7}$ & $1.05(1.03-1.07)$ & $2.3 \times 10^{-5}$ \\
\hline rs 146170568 & 17 & $40,517,716$ & $\mathrm{~T}$ & 0.005 & 42,510 & 40,577 & $1.32(1.16-1.50)$ & $2.1 \times 10^{-5}$ & $1.27(1.11-1.44)$ & $3.2 \times 10^{-4}$ \\
\hline rs 141732716 & 17 & $40,469,832$ & A & 0.005 & 42,510 & 40,577 & $1.38(1.14-1.68)$ & 0.001 & $1.33(1.09-1.62)$ & 0.004 \\
\hline rs138391971 & 17 & $40,505,106$ & $\mathrm{G}$ & 0.003 & 42,510 & 40,577 & $0.60(0.43-0.83)$ & 0.002 & $0.61(0.44-0.85)$ & 0.003 \\
\hline rs12952342 & 17 & $40,553,640$ & G & 0.119 & 42,510 & 40,577 & $1.07(1.03-1.12)$ & 0.002 & $1.07(1.02-1.11)$ & 0.005 \\
\hline rs 190765034 & 17 & $40,428,622$ & G & 0.026 & 42,510 & 40,577 & $1.14(1.03-1.25)$ & 0.010 & $1.17(1.06-1.29)$ & 0.002 \\
\hline rs190137766 & 17 & $40,422,371$ & $\mathrm{~T}$ & 0.002 & 42,510 & 40,577 & $0.68(0.50-0.94)$ & 0.018 & $0.66(0.48-0.90)$ & 0.009 \\
\hline
\end{tabular}

SNP single nucleotide polymorphism, Chr. chromosome, OR odds ratio, CI confidence interval, STAT3 signal transducer and activator of transcription 3

${ }^{a}$ Build 37

b Allele frequency (AF) of counted allele

c OR per counted allele, adjusted for age, study and 16 European principal components

d Each SNP was tested adjusting for rs8074296, age, study and 16 European principal components. Estimate for rs 8074296 is based on model including rs 146170568

CCND1 have been identified as breast cancer susceptibility loci in previous studies (French et al. 2013; Michailidou et al. 2013; Rhie et al. 2013), we focused on the association of the SNP at STAT3. The variant rs1905339 $(\mathrm{A}>\mathrm{G})$ at STAT3 was positively associated with overall breast cancer risk (per allele odds ratio (OR) 1.05, $95 \%$ confidence interval $(\mathrm{CI}) 1.03-1.08, p$ value $\left.=1.4 \times 10^{-6}\right)$. It showed similar associations with ER-positive and ER-negative cancers (Online Resource 5). We did not observe further SNPs that were significantly associated with ER-positive or ER-negative disease (data not shown).

To identify additional susceptibility variants at STAT3, we further investigated 707 SNPs that were well-imputed (imputation accuracy $r^{2}>0.3$ ) and with MAF $>0.01$ spanning a $\pm 50 \mathrm{~kb}$ window around STAT3. Seven independent signals at STAT3 were found through the stepwise forward selection procedure. The genotyped SNP rs1905339 was not selected. The imputed SNP rs8074296 $(\mathrm{A}>\mathrm{G})$, which was in high LD with $\mathrm{rs} 1905339\left(r^{2}=0.99\right)$, showed a comparable OR for the association with overall breast cancer risk with a more extreme $p$ value (per allele OR 1.05, 95\% CI 1.03-1.08, $p$ value $=8.6 \times 10^{-7}$, Table 3). A second imputed SNP rs146170568 (C>T), associated with a per allele OR of $1.32(95 \% \mathrm{CI}$ $1.16-1.50, \quad p$ value $=2.1 \times 10^{-5}$ ), was still strongly associated at a $p$ value of $3.2 \times 10^{-4}$ after accounting for rs8074296 (Table 3). None of the independently associated imputed SNPs besides rs8074296 were correlated with rs1905339 or with each other $\left(r^{2} \leq 0.01\right.$, Fig. 1). As rs8074296 and rs1905339 are located closer to PTRF than to STAT3, we additionally analyzed data of 178 imputed variants located within $\pm 50 \mathrm{~kb}$ of $P T R F$. Associations of most additional variants in the PTRF region with breast cancer risk were attenuated in analyses conditioning on rs8074296 (Table 4). The variants chr17:40607850:I and rs77942990 still showed a strong association with breast cancer risk (per allele OR 1.09, $95 \%$ CI 1.04-1.15, $p$ value $=0.0005$; and per allele OR 1.09, $95 \% \mathrm{CI}$ $1.04-1.15, p$ value $=0.0007$, respectively). These two variants were also not in LD with rs8074296 $\left(r^{2}=0.09\right.$ 
Fig. 1 Linkage disequilibrium plot showing $r^{2}$ values and color schemes for the genotyped SNP rs1905339 and seven independent imputed SNPs as well as imputed SNP rs181888151 within $\pm 50 \mathrm{~kb}$ of STAT3. The linkage disequilibrium (LD) plot shows that SNP rs1905339 is in strong LD with the imputed SNP rs8074296 $\left(r^{2}=0.99\right)$, and independent of the other six imputed SNPs $\left(r^{2} \leq 0.01\right)$ at STAT3. LD was estimated based on control data

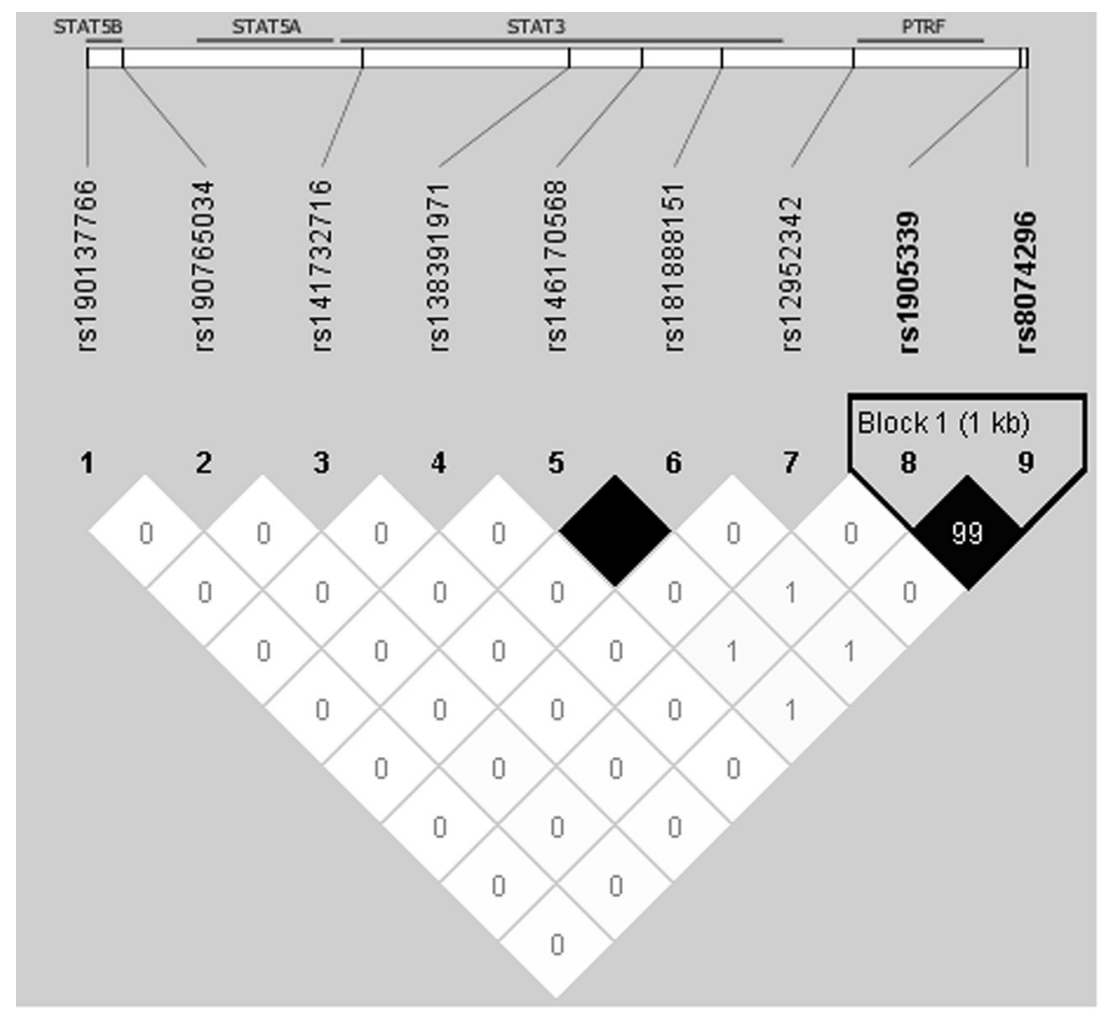

and 0.07 , respectively) while all other variants in Table 4 were at least in moderate LD with rs8074296 $\left(r^{2} \geq 0.46\right.$, Online Resource 6). The LD plot (Online Resource 6) also shows that chr17:40607850:I and rs77942990 are in high LD $\left(r^{2}=0.83\right)$. A regional association plot for the genotyped SNP rs1905339 and all 885 imputed SNPs within $\pm 50 \mathrm{~kb}$ of STAT3 and PTRF included in this analysis is shown in Fig. 2. Associations of SNPs shown in Table 3 as well as associations of chr17:40607850:I and rs77942990 with breast cancer risk were not significantly heterogeneous between studies (all $p$ values for heterogeneity $>0.1$ ) ; forest plots can be found in Online Resource 7 to 16.

\section{Gene-level and pathway associations}

Gene-level associations with risks of overall breast cancer, ER-positive and ER-negative diseases, respectively, for the 133 candidate genes in the immunosuppression pathway are summarized in Online Resource 17. TGFBR2 and $C C N D 1$ showed significant associations with overall breast cancer risk ( $p$ value $<10^{-6}$ and $3.0 \times 10^{-4}$, respectively). In addition, IL5 and GM-CSF may be further potential susceptibility loci of breast cancer $\left(p\right.$ value $=1.0 \times 10^{-3}$ and $7.0 \times 10^{-3}$, respectively). STAT3 showed a less significant association with overall breast cancer risk ( $p$ value $=0.033$ ). The immunosuppression pathway as a whole yielded a significant association with overall breast cancer risk ( $p$ value $<10^{-6}$ ). Similar gene-level and pathway associations were found for ER-positive but not for ER-negative breast cancer (Online Resource 17). We found significant enrichment of association in the immunosuppression pathway based on the results of the single SNPs association analyses (313 of 3595 tests significant at $\alpha=0.05$, exact binomial test $p$ value $=2.2 \times 10^{-16}$ ).

\section{Haplotype analyses}

Despite the evidence for a possible role of IL5 and GM$C S F$ in breast cancer susceptibility from the gene-level analysis, no individual SNPs at IL5 or GM-CSF yielded significant genetic associations. To identify potential susceptibility haplotypes, haplotype-specific associations were assessed based on seven SNPs in or near IL5 (rs4143832, rs2079103, rs2706399, rs743562, rs739719, rs2069812 and rs2244012) and nine SNPs in or near GM-CSF (rs11575022, rs2069616, rs25881, rs25882, rs25883, rs27349, rs27438, rs40401 and rs743564). The LD structures for these SNPs at IL5 and GM-CSF are shown in Online Resource 18 and 19, respectively. In our study sample of women of European ancestry, 11 and 7 common haplotypes with frequency $>1 \%$ were observed at IL5 and $G M-C S F$, respectively. The haplotype AAAACGG in IL5 was associated with a decreased overall breast cancer risk (OR 0.96, $95 \%$ CI 0.93-0.99, $p$ value $=5.0 \times 10^{-3}$, Table 5). In GM-CSF, the haplotype AAGAGCGAA was 
Table 4 Associations with overall breast cancer risk for 19 imputed variants near PTRF in women of European ancestry

\begin{tabular}{|c|c|c|c|c|c|c|c|c|c|c|c|c|}
\hline \multirow[t]{2}{*}{ SNP } & \multirow[t]{2}{*}{$\mathrm{Chr}$} & \multirow[t]{2}{*}{ Position $^{a}$} & \multirow{2}{*}{$\begin{array}{l}\text { Counted } \\
\text { allele }\end{array}$} & \multirow[t]{2}{*}{$\mathrm{AF}^{\mathrm{b}}$} & \multirow[t]{2}{*}{ Cases } & \multirow[t]{2}{*}{ Controls } & \multicolumn{3}{|c|}{ Single SNP analysis } & \multicolumn{3}{|c|}{ Conditional analysis ${ }^{\mathrm{d}}$} \\
\hline & & & & & & & $\mathrm{OR}^{\mathrm{c}}$ & $(95 \% \mathrm{CI})$ & $p$ value & $\mathrm{OR}^{\mathrm{c}}$ & $(95 \% \mathrm{CI})$ & $p$ valu \\
\hline s8074296 & 17 & $40,583,421$ & $\mathrm{G}$ & 0.336 & 42,510 & 40,577 & 1.05 & (1.03-1.08) & $8.6 \times 10^{-7}$ & 1.04 & $(1.02-1.06)$ & 0.0006 \\
\hline rs 1032070 & 17 & $40,618,251$ & $\mathrm{~T}$ & 0.269 & 42,510 & 40,577 & 1.06 & (1.04-1.09) & $1.5 \times 10^{-7}$ & 1.04 & (1.00-1.09) & 0.0359 \\
\hline rs34460267 & 17 & $40,615,865$ & $\mathrm{C}$ & 0.269 & 42,510 & 40,577 & 1.06 & (1.04.1.09) & $1.9 \times 10^{-7}$ & 1.04 & (1.00-1.09) & 0.0424 \\
\hline rs34807589 & 17 & $40,624,656$ & $\mathrm{~T}$ & 0.264 & 42,510 & 40,577 & 1.06 & (1.04-1.09) & $2.0 \times 10^{-7}$ & 1.04 & (1.00-1.09) & 0.0423 \\
\hline rs36005199 & 17 & $40,597,555$ & G & 0.268 & 42,510 & 40,577 & 1.06 & (1.04-1.09) & $2.1 \times 10^{-7}$ & 1.04 & (1.00-1.09) & 0.0490 \\
\hline rs12603201 & 17 & $40,595,927$ & $\mathrm{~T}$ & 0.581 & 42,510 & 40,577 & 0.95 & $(0.93-0.97)$ & $3.1 \times 10^{-7}$ & 0.97 & (0.93-1.00) & 0.0662 \\
\hline chr17:40607850:I & 17 & $40,607,850$ & CT & 0.055 & 42,510 & 40,577 & 1.13 & $(1.07-1.18)$ & $7.0 \times 10^{-7}$ & 1.09 & $(1.04-1.15)$ & 0.0005 \\
\hline rs4796662 & 17 & $40,594,882$ & $\mathrm{C}$ & 0.576 & 42,510 & 40,577 & 0.95 & $(0.93-0.97)$ & $1.8 \times 10^{-6}$ & 0.98 & $(0.94-1.01)$ & 0.2217 \\
\hline rs34349578 & 17 & $40,598,129$ & A & 0.195 & 42,510 & 40,577 & 1.07 & $(1.04-1.10)$ & $2.1 \times 10^{-6}$ & 1.04 & $(1.00-1.08)$ & 0.0809 \\
\hline$s 62075801$ & 17 & $40,593,921$ & $\mathrm{~T}$ & 0.576 & 42,510 & 40,577 & 0.95 & $(0.93-0.97)$ & $2.1 \times 10^{-6}$ & 0.98 & $(0.94-1.01)$ & 0.2385 \\
\hline$s 12951640$ & 17 & $40,594,298$ & A & 0.253 & 42,510 & 40,577 & 1.06 & (1.03-1.08) & $2.1 \times 10^{-6}$ & 1.03 & $(0.98-1.07)$ & 0.2269 \\
\hline rs77942990 & 17 & $40,622,538$ & A & 0.046 & 42,510 & 40,577 & 1.13 & $(1.07-1.19)$ & $2.2 \times 10^{-6}$ & 1.09 & $(1.04-1.15)$ & 0.0007 \\
\hline rs 35111218 & 17 & $40,595,572$ & $\mathrm{~T}$ & 0.252 & 42,510 & 40,577 & 1.06 & (1.03-1.08) & $2.3 \times 10^{-6}$ & 1.03 & $(0.98-1.07)$ & 0.2311 \\
\hline rs6503704 & 17 & $40,592,253$ & A & 0.253 & 42,510 & 40,577 & 1.06 & $(1.03-1.08)$ & $2.3 \times 10^{-6}$ & 1.03 & $(0.98-1.07)$ & 0.2413 \\
\hline rs12943498 & 17 & $40,593,901$ & $\mathrm{C}$ & 0.253 & 42,510 & 40,577 & 1.06 & $(1.03-1.08)$ & $2.5 \times 10^{-6}$ & 1.02 & $(0.98-1.07)$ & 0.2529 \\
\hline rs12951549 & 17 & $40,593,502$ & $\mathrm{~T}$ & 0.253 & 42,510 & 40,577 & 1.06 & $(1.03-1.08)$ & $2.6 \times 10^{-6}$ & 1.02 & $(0.98-1.07)$ & 0.2537 \\
\hline chr17:40593802:I & 17 & $40,593,802$ & GTTTC & 0.251 & 42,510 & 40,577 & 1.06 & (1.03-1.08) & $3.5 \times 10^{-6}$ & 1.02 & $(0.98-1.07)$ & 0.2943 \\
\hline rs6503703 & 17 & $40,592,207$ & $\mathrm{~T}$ & 0.261 & 42,510 & 40,577 & 1.06 & $(1.03-1.08)$ & $6.5 \times 10^{-6}$ & 1.02 & $(0.98-1.06)$ & 0.3775 \\
\hline chr17:40595896:D & 17 & $40,595,896$ & $\mathrm{C}$ & 0.211 & 42,510 & 40,577 & 1.06 & $(1.03-1.09)$ & $9.0 \times 10^{-6}$ & 1.02 & $(0.98-1.07)$ & 0.2373 \\
\hline
\end{tabular}

SNP single nucleotide polymorphism, Chr. chromosome, OR odds ratio, CI confidence interval, STAT3 signal transducer and activator of transcription 3

a Build 37

b Allele frequency (AF) of counted allele

${ }^{\mathrm{c}}$ OR per counted allele, adjusted for age, study and 16 European principal components

${ }^{d}$ Each SNP was tested adjusting for rs8074296, age, study and 16 European principal components. Estimate for rs8074296 was based on model including chr17:40607850:I

Fig. 2 Regional association plot for the genotyped SNP rs1905339 and 885 imputed SNPs within $\pm 50 \mathrm{~kb}$ of STAT3 and PTRF. Each dot represents an SNP. The color of each dot reflects the extent of linkage disequilibrium $\left(r^{2}\right)$ with SNP rs1032070 (in purple diamond). Genomic positions of SNPs were plotted based on hg19/ 1000 Genomes Mar 2012 European. Association is represented at the $-\log 10$ scale. $c M / M b$ centiMorgans/megabase

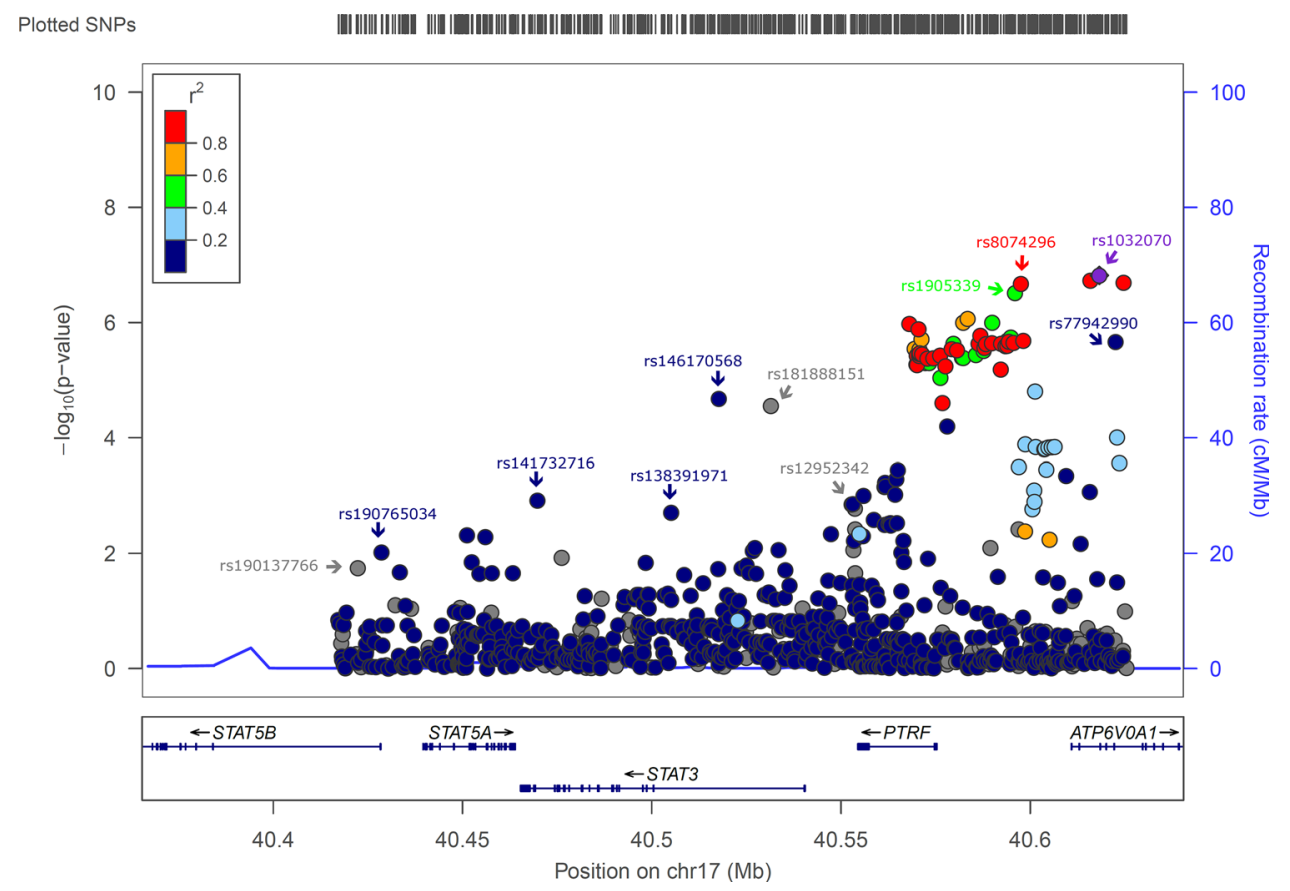




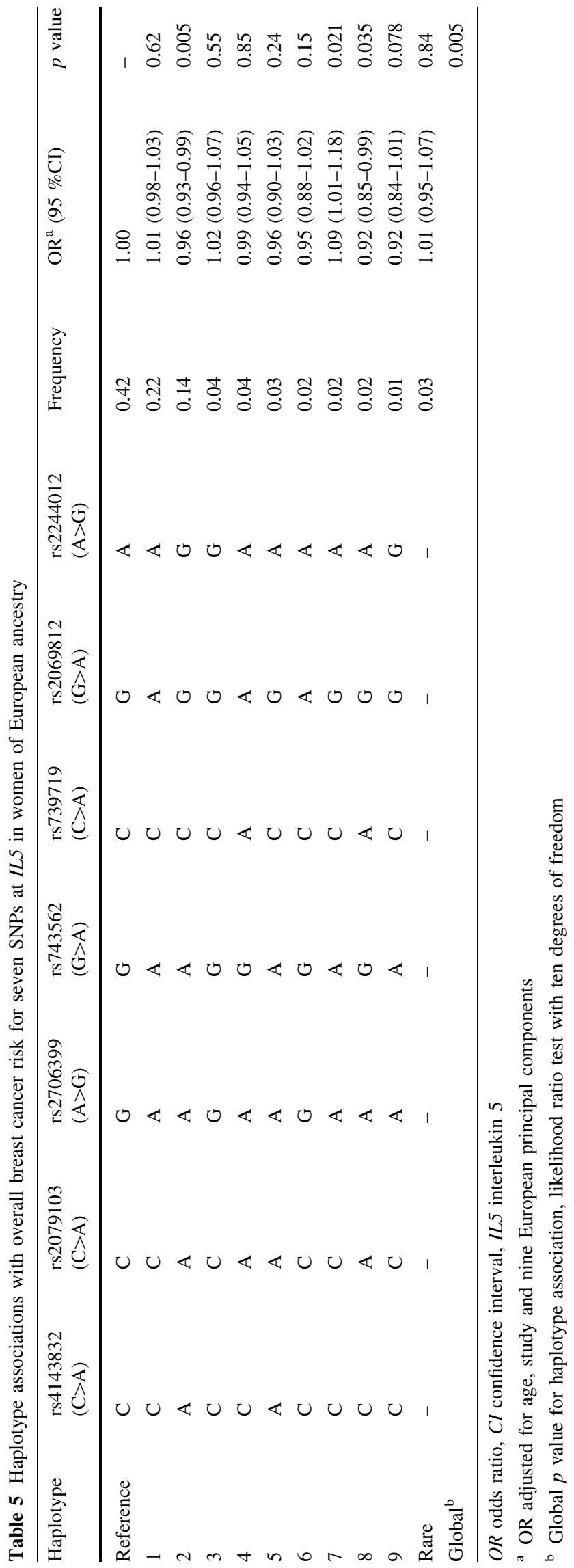

also associated with a decreased overall breast cancer risk (OR 0.92, $95 \%$ CI $0.87-0.96, p$ value $=2.7 \times 10^{-4}$, Table 6). The global $p$ value for haplotype association was significant for both IL5 ( $p$ value $=0.005)$ and $G M-C S F$ $(p$ value $=0.007)$.

\section{Gene expression analyses}

Using TCGA RNA sequencing level 3 data, we found that RNA expression levels of STAT3 and IL5 were significantly higher in 113 normal tissue samples compared to 989 breast tumor samples ( $p$ value $=1.3 \times 10^{-3}$ and $7.0 \times 10^{-4}$, respectively, Online Resources 20 and 21), while overall expression of IL5 was low in both tissues. Also expression levels of PTRF were significantly higher in normal tissue compared to tumor tissue samples ( $p$ value $\leq 0.0001$, Online Resource 22 ). GM-CSF expression was very low and did not differ between breast tumor samples and normal tissue samples ( $p$ value $=0.49$, Online Resource 23). Among 183 mammary tissues in the GTEx database, SNPs rs1905339, rs8074296 and rs77942990 were not significantly correlated with STAT3 ( $p$ values $=0.36,0.36$, and 0.2 , respectively; Online Resource 24 to 26 ) or PTRF expression ( $p$ values $=0.4$, 0.4 , and 0.39 Online Resource 27 to 29). The SNPs rs1905339 and rs8074296 were significant eQTL for TUBG2 (both $p$ values $=9.9 \times 10^{-7}$, Online Resource 30 and 31). The STAT3/PTRF variants rs 146170568 and chr17:40607850:I were not available in the GTEx database.

\section{Discussion}

Our comprehensive examination of associations between polymorphisms in the immunosuppression pathway genes and breast cancer risk revealed that STAT3, IL5, and GM$C S F$ may play a role in overall breast cancer susceptibility among women of European ancestry.

The in silico functional analysis revealed that within a $\pm 50 \mathrm{~kb}$ window of STAT3, several polymorphisms are located in regulatory regions that could actively affect DNA transcription (Fig. 3). The SNP rs181888151, which is in complete LD with rs146170568 $\left(r^{2}=1\right)$ but independent of rs1905339 $\left(r^{2}=0.01\right.$, Fig. 1$)$ was significantly associated with increased risk for overall breast cancer (per allele OR 1.31, $95 \%$ CI 1.16-1.49, $p$ value $=$ $2.8 \times 10^{-5}$ ). Together with a further independently associated imputed SNP rs141732716, these polymorphisms reside in strong DNase I hypersensitivity and transcription regulatory sites (Fig. 3). This suggests that they may be functional polymorphisms, but further experimental work is required for confirmation. 


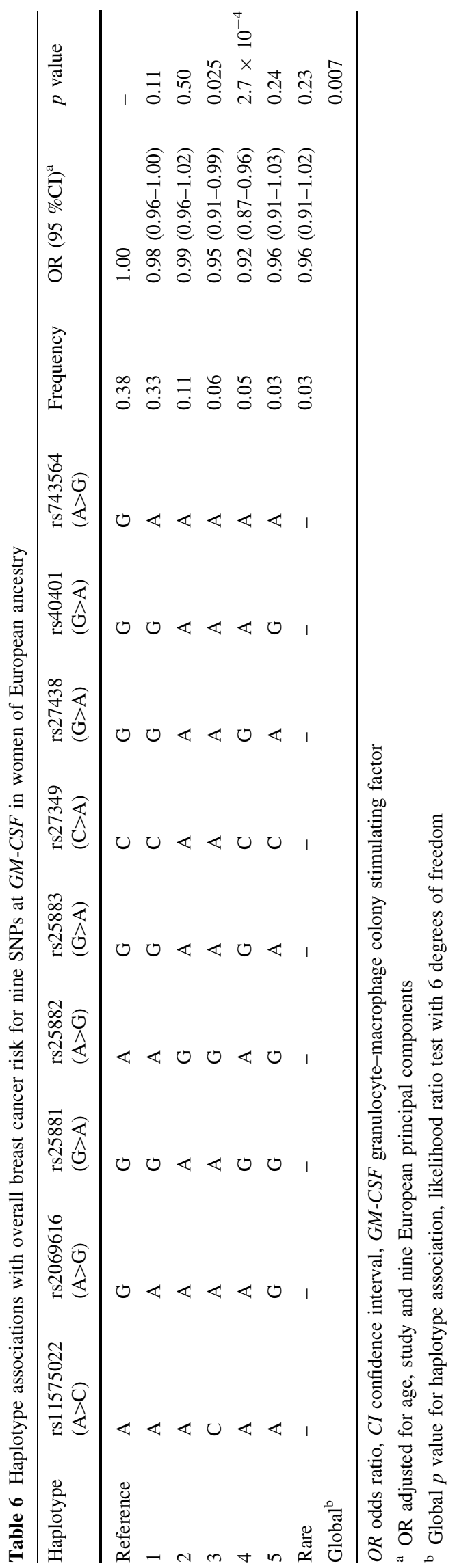

STAT3 encodes the signal transducer and activator of transcription 3, which is a member of the STAT protein family. Activated by corresponding cytokines or growth factors, STAT3 can be phosphorylated and translocate into the cell nucleus, acting as a transcription activator. In addition, STAT3 plays a key role in regulating immune response in the tumor microenvironment ( $\mathrm{Yu}$ et al. 2009). STAT3 signaling is required for immunosuppressive and tumor-promoting functions of MDSCs (Cheng et al. 2003, 2008; Kortylewski et al. 2005, 2009; Kujawski et al. 2008; Ostrand-Rosenberg and Sinha 2009; Yu et al. 2009), as well as for Treg cell expansion (Kortylewski et al. 2005, 2009; Matsumura et al. 2007). STAT3 has been reported in several previous genome-wide association studies (GWAS) to be associated with immune relevant diseases such as Crohn's disease (Barrett et al. 2008; Franke et al. 2008; Yamazaki et al. 2013), inflammatory bowel disease (Jostins et al. 2012), and multiple sclerosis (Jakkula et al. 2010; Patsopoulos et al. 2011; Sawcer et al. 2011). Additionally, expression of STAT3 was suggested to be enriched in triple-negative breast cancer, and negatively associated with lymph node involvement and breast tumor stage in a study based on an in silico network approach (Liu et al. 2012b). However, the association of rs1905339 with triple-negative breast cancer risk in our study ( $\mathrm{N}$ triple-negative breast cancer $=2600$ ) was similar and not stronger compared to the association observed for overall breast cancer risk (per allele OR 1.06, $95 \%$ CI 0.99-1.14, $p$ value $=0.11$ ).

The genotyped SNP rs1905339 is also located at $7 \mathrm{~kb} 5^{\prime}$ of PTRF, which encodes the polymerase I and transcript release factor, and is not known to be directly involved in immunosuppression. In addition, two independently associated imputed SNPs rs8074296 and rs12952342 $\left(r^{2}=0.99\right.$ and 0 with rs 1905339, respectively, Fig. 1) are located at $8 \mathrm{~kb} 5^{\prime}$ and $0.8 \mathrm{~kb} \mathrm{3}$ of PTRF, respectively (Fig. 3). PTRF is known to contribute to the formation of caveolae, small membrane caves involved in cell signaling, lipid regulation, and endocytosis (Chadda and Mayor 2008). Recently, downregulation of $P T R F$ was observed in breast cancer cell lines and breast tumor tissue, suggesting that PTRF expression might be an indicator for breast cancer progression (Bai et al. 2012). The SNPs rs1905339 and rs8074296 were also found to be eQTL for TUBG2 (tubulin, gamma 2) in the GTEx database, the expression of TUBG 2 decreased with each variant allele (Online Resources 30 and 31, respectively). TUBG2 encodes $\gamma$-tubulin, a protein required for the formation and polar orientation of microtubules in cells. It is currently unknown, whether TUBG2 plays a role in breast cancer development or progression.

The other two potential susceptibility loci, IL5 and GM$C S F$, are both located in a known cytokine gene cluster at 5q31. IL5 encodes interleukin 5, a cytokine secreted by CD4+ T helper 2 cells (Mills 2004; Parker 1993). IL5 is a 


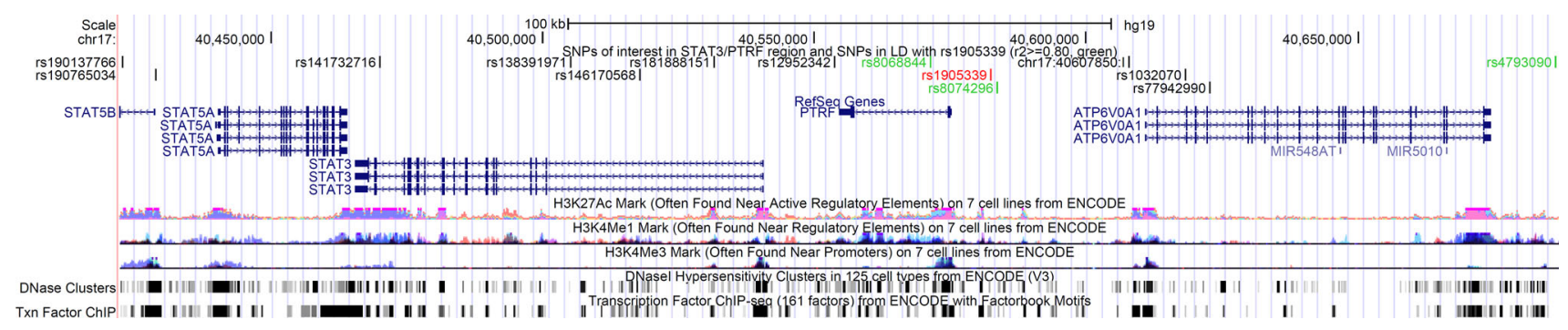

Fig. 3 UCSC genome browser graphic for SNPs at the STAT3/PTRF region. The UCSC genome browser graphic shows functional annotations for the SNPs rs1905339 (red), correlated SNPs $\left(r^{2}>0.80\right.$, green $)$, as well as the other independent imputed SNPs (black) in or near the STAT3/PTRF region growth and differentiation factor for both $\mathrm{B}$ cells and eosinophils, triggering eosinophil- and B cell-dependent immune response (Mills 2004; Parker 1993). GM-CSF encodes granulocyte-macrophage colony stimulating factor, a cytokine that controls differentiation and function of granulocytes and macrophages. GM-CSF is also a MDSCinducing and activating factor in the bone marrow (Ostrand-Rosenberg and Sinha 2009; Serafini et al. 2004). In the tumor microenvironment, GM-CSF is the cytokine for dendritic cell differentiation and function, and it is often found to be underexpressed (Zou 2005). Additionally, 5q31 has been found to be a susceptibility locus for rheumatoid arthritis (Okada et al. 2012, 2014) and inflammatory bowel disease (Jostins et al. 2012).

Immunosuppression is a complex network with plenty of contributors, including transcription factors (e.g., STAT3), as well as immune mediating cytokines (e.g., IL5 and GM-CSF). Results of this analysis indicate that genetic variation in different components of the immunosuppression pathway may be susceptibility loci of breast cancer among women of European ancestry.

The main strengths of the present analysis were its large sample size, the uniform genotyping procedures and centralized quality controls used. The imputation of genotypes in the most interesting susceptibility loci provided an opportunity to identify more strongly associated variants. Assessments of gene-level associations also provided evidence for additional putative susceptibility loci. A limitation was the lack of an independent sample to replicate the observed associations; this will be feasible in the future using new studies participating in the BCAC. Further functional studies are still needed to identify causal variants and to investigate the underlying biological mechanisms.

\section{Conclusions}

Overall, our data provide strong evidence that common variation in the immunosuppression pathway is associated with breast cancer susceptibility. The strongest candidates for mediating this association were STAT3, IL5, and GM$C S F$, but we cannot exclude the possibility of multiple alleles each with effects too small to confirm.

Acknowledgments We thank all the individuals who took part in these studies and all the researchers, clinicians, technicians, and administrative staff who have enabled this work to be carried out. This analysis would not have been possible without the contributions of the following: Per Hall (COGS); Douglas F. Easton, Paul Pharoah, Kyriaki Michailidou, Manjeet K. Bolla, Qin Wang (BCAC), Andrew Berchuck (OCAC), Rosalind A. Eeles, Douglas F. Easton, Ali Amin Al Olama, Zsofia Kote-Jarai, Sara Benlloch (PRACTICAL), Georgia Chenevix-Trench, Antonis Antoniou, Lesley McGuffog, Fergus Couch and Ken Offit (CIMBA), Joe Dennis, Alison M. Dunning, Andrew Lee, and Ed Dicks, Craig Luccarini and the staff of the Centre for Genetic Epidemiology Laboratory, Javier Benitez, Anna Gonzalez-Neira and the staff of the CNIO genotyping unit, Jacques Simard and Daniel C. Tessier, Francois Bacot, Daniel Vincent, Sylvie LaBoissière and Frederic Robidoux and the staff of the McGill University and Génome Québec Innovation Centre, Stig E. Bojesen, Sune F. Nielsen, Borge G. Nordestgaard, and the staff of the Copenhagen DNA laboratory, and Julie M. Cunningham, Sharon A. Windebank, Christopher A. Hilker, Jeffrey Meyer and the staff of Mayo Clinic Genotyping Core Facility. ABCFS would like to thank Maggie Angelakos, Judi Maskiell, and Gillian Dite. ABCS would like to thank Sanquin Amsterdam, the Netherlands. BBCS thanks Eileen Williams, Elaine Ryder-Mills, and Kara Sargus. BIGGS thanks Niall McInerney, Gabrielle Colleran, Andrew Rowan, and Angela Jones. BSUCH would like to thank Peter Bugert and Medical Faculty Mannheim. CGPS thanks Staff and participants of the Copenhagen General Population Study, as well as excellent technical assistance from Dorthe Uldall Andersen, Maria Birna Arnadottir, Anne Bank, and Dorthe Kjeldgård Hansen. CNIO-BCS would like to thank Guillermo Pita, Charo Alonso, Daniel Herrero, Nuria Álvarez, Pilar Zamora, Primitiva Menendez, and the Human Genotyping-CEGEN Unit. CTS would like to thank the CTS Steering Committee including Leslie Bernstein, Susan Neuhausen, James Lacey, Sophia Wang, Huiyan Ma, Yani Lu, and Jessica Clague DeHart at the Beckman Research Institute of City of Hope, Dennis Deapen, Rich Pinder, Eunjung Lee, and Fred Schumacher at the University of Southern California, Pam Horn-Ross, Peggy Reynolds, Christina Clarke Dur and David Nelson at the Cancer Prevention Institute of California, and Hoda Anton-Culver, Argyrios Ziogas, and Hannah Park at the University of California Irvine. ESTHER thanks Hartwig Ziegler, Christa Stegmaier, Sonja Wolf, and Volker Hermann. GC-HBOC thanks Stefanie Engert, Heide Hellebrand, and Sandra Kröber. GENICA would like to thank the GENICA Network, including Dr. Margarete Fischer-Bosch-Institute of Clinical Pharmacology, Stuttgart, and University of Tübingen, Germany (HB, Wing-Yee Lo, 
Christina Justenhoven), German Cancer Consortium (DKTK) and Deutsches Krebsforschungszentrum (DKFZ) (HB), Department of Internal Medicine, Evangelische Kliniken Bonn gGmbH, Johanniter Krankenhaus, Bonn, Germany (Yon-Dschun Ko, Christian Baisch), Institute of Pathology, University of Bonn, Germany (Hans-Peter Fischer), Molecular Genetics of Breast Cancer, DKFZ, Heidelberg, Germany (UH), Institute for Prevention and Occupational Medicine of the German Social Accident Insurance, Institute of the Ruhr University Bochum (IPA), Bochum, Germany (Thomas Brüning, Beate Pesch, Sylvia Rabstein, Anne Lotz), and Institute of Occupational Medicine and Maritime Medicine, University Medical Center Hamburg-Eppendorf, Germany (Volker Harth). HEBCS would like to thank Kirsimari Aaltonen, Karl von Smitten, Sofia Khan, Tuomas Heikkinen, and Irja Erkkilä. HMBCS would like to thank Peter Hillemanns, Hans Christiansen, and Johann H. Karstens. KBCP thanks Eija Myöhänen and Helena Kemiläinen. LMBC thanks Gilian Peuteman, Dominiek Smeets, Thomas Van Brussel, and Kathleen Corthouts. MARIE would like to thank Petra Seibold, Judith Heinz, Nadia Obi, Alina Vrieling, Muhabbet Celik, Til Olchers, and Stefan Nickels. MBCSG thanks Siranoush Manoukian, Bernard Peissel and Daniela Zaffaroni at the Fondazione IRCCS Istituto Nazionale dei Tumori (INT), Monica Barile and Irene Feroce at the Istituto Europeo di Oncologia (IEO), and the personnel of the Cogentech Cancer Genetic Test Laboratory. MTLGEBCS would like to thank Martine Tranchant at the CHU de Québec Research Center, Marie-France Valois, Annie Turgeon and Lea Heguy at the McGill University Health Center, Royal Victoria Hospital, McGill University for DNA extraction, sample management and skillful technical assistance, and J.S. who is the Chairholder of the Canada Research Chair in Oncogenetics. NBCS would like to thank Dr. Kristine Kleivi, PhD (K.G. Jebsen Centre for Breast Cancer Research, Institute of Clinical Medicine, University of Oslo, Oslo, Norway and Department of Research, Vestre Viken, Drammen, Norway), Dr. Lars Ottestad, MD (Department of Genetics, Institute for Cancer Research, Oslo University Hospital Radiumhospitalet, Oslo, Norway), Prof. Em. Rolf Kåresen, MD (Department of Oncology, Oslo University Hospital and Faculty of Medicine, University of Oslo, Oslo, Norway), Dr. Anita Langerød, PhD (Department of Genetics, Institute for Cancer Research, Oslo University Hospital Radiumhospitalet, Oslo, Norway), Dr. Ellen Schlichting, MD (Department for Breast and Endocrine Surgery, Oslo University Hospital Ullevaal, Oslo, Norway), Dr. Marit Muri Holmen, MD (Department of Radiology and Nuclear Medicine, Oslo University Hospital, Oslo, Norway), Prof. Toril Sauer, MD (Department of Pathology at Akershus University hospital, Lørenskog, Norway), Dr. Vilde Haakensen, MD (Department of Genetics, Institute for Cancer Research, Oslo University Hospital Radiumhospitalet, Oslo, Norway), Dr. Olav Engebråten, MD (Institute for Clinical Medicine, Faculty of Medicine, University of Oslo and Department of Oncology, Oslo University Hospital, Oslo, Norway), Prof. Bjørn Naume, MD (Division of Cancer Medicine and Radiotherapy, Department of Oncology, Oslo University Hospital Radiumhospitalet, Oslo, Norway), Dr. Cecile E. Kiserud, MD (National Advisory Unit on Late Effects after Cancer Treatment, Department of Oncology, Oslo University Hospital, Oslo, Norway and Department of Oncology, Oslo University Hospital, Oslo, Norway), Dr. Kristin V. Reinertsen, MD (National Advisory Unit on Late Effects after Cancer Treatment, Department of Oncology, Oslo University Hospital, Oslo, Norway and Department of Oncology, Oslo University Hospital, Oslo, Norway), Assoc. Prof. Åslaug Helland, MD (Department of Genetics, Institute for Cancer Research and Department of Oncology, Oslo University Hospital Radiumhospitalet, Oslo, Norway), Dr. Margit Riis, MD (Dept of Breast- and Endocrine Surgery, Oslo University Hospital, Ullevål, Oslo, Norway), Dr. Ida Bukholm, MD (Department of Breast-Endocrine Surgery, Akershus University Hospital, Oslo, Norway and Department of Oncology, Division of Cancer Medicine, Surgery and Transplantation, Oslo University
Hospital, Oslo, Norway), Prof. Per Eystein Lønning, MD (Section of Oncology, Institute of Medicine, University of Bergen and Department of Oncology, Haukeland University Hospital, Bergen, Norway), Dr Silje Nord, PhD (Department of Genetics, Institute for Cancer Research, Oslo University Hospital Radiumhospitalet, Oslo, Norway) and Grethe I. Grenaker Alnæs, M.Sc. (Department of Genetics, Institute for Cancer Research, Oslo University Hospital Radiumhospitalet, Oslo, Norway). NBHS would like to thank study participants and research staff for their contributions and commitment to this study. OBCS thanks Meeri Otsukka and Kari Mononen. OFBCR thanks Teresa Selander and Nayana Weerasooriya. PBCS thanks Louise Brinton, Mark Sherman, Neonila Szeszenia-Dabrowska, Beata Peplonska, Witold Zatonski, Pei Chao, and Michael Stagner. SASBAC would like to thank the Swedish Medical Research Counsel. SBCS would like to thank Sue Higham, Helen Cramp, Ian Brock, Sabapathy Balasubramanian, and Dan Connley. SEARCH thanks the SEARCH and EPIC teams. SKKDKFZS thanks all study participants, clinicians, family doctors, researchers and technicians for their contributions and commitment to this study. TNBCC thanks Robert Pilarski and Charles Shapiro who were instrumental in the formation of the OSU Breast Cancer Tissue Bank, and also thanks the Human Genetics Sample Bank for processing of samples and providing OSU Columbus area control samples. UKBGS would like to thank Breast Cancer Now and the Institute of Cancer Research for support and funding of the Breakthrough Generations Study, and the study participants, study staff, and the doctors, nurses and other health care providers and health information sources who have contributed to the study, and acknowledge the NHS funding to the Royal Marsden/ICR NIHR Biomedical Research Centre. kConFab/AOCS wish to thank Heather Thorne, Eveline Niedermayr, all the kConFab research nurses and staff, the heads and staff of the Family Cancer Clinics, and the Clinical Follow Up Study (which has received funding from the NHMRC, the National Breast Cancer Foundation, Cancer Australia, and the National Institute of Health (USA)) for their contributions to this resource, and many families who contribute to kConFab. pKARMA would like to thank the Swedish Medical Research Counsel.

\section{Compliance with ethical standards}

Conflict of interest The authors declare that they have no competing interests.

Financial supports Funding for the iCOGS infrastructure came from: the European Community's Seventh Framework Programme under grant agreement number 223175 (HEALTH-F2-2009-223175) (COGS), Cancer Research UK (C1287/A10118, C1287/A10710, C12292/A11174, C1281/A12014, C5047/A8384, C5047/A15007, C5047/A10692, C8197/A16565), the National Institutes of Health (NIH, CA128978, CA122443) and Post-Cancer GWAS initiative (1U19 CA148537, 1U19 CA148065 and 1U19 CA148112-the GAME-ON initiative), the Department of Defence (W81XWH-10-10341), the Canadian Institutes of Health Research (CIHR) for the CIHR Team in Familial Risks of Breast Cancer, Komen Foundation for the Cure, the Breast Cancer Research Foundation, and the Ovarian Cancer Research Fund. BCAC is funded by Cancer Research UK (C1287/A10118, C1287/A12014) and by the European Communitýs Seventh Framework Programme under grant agreement number 223175 (grant number HEALTH-F2-2009-223175) (COGS). The ABCFS study was supported by grant UM1 CA164920 from the National Cancer Institute (USA). This study was also supported by the National Health and Medical Research Council of Australia, the New South Wales Cancer Council, the Victorian Health Promotion Foundation (Australia) and the Victorian Breast Cancer Research Consortium. The ABCS study was supported by the Dutch Cancer Society (grants NKI 2007-3839; 2009 4363), and Biobanking and 
BioMolecular resources Research Infrastructure-Netherlands (BBMRI-NL), which is a Research Infrastructure financed by the Dutch government (NWO 184.021.007). The work of the BBCC was partly funded by ELAN-Fond of the University Hospital of Erlangen. The BBCS study was funded by Cancer Research UK and Breakthrough Breast Cancer and acknowledges National Health Service (NHS) funding to the National Institute for Health Research (NIHR) Biomedical Research Centre, and the National Cancer Research Network (NCRN). The BIGGS study was supported by NIHR Comprehensive Biomedical Research Centre, Guy's \& St. Thomas' NHS Foundation Trust in partnership with King's College London, United Kingdom. IT was supported by the Oxford Biomedical Research Centre. The BSUCH study was supported by the DietmarHopp Foundation, the Helmholtz Society and the Deutsches Krebsforschungszentrum (DKFZ). The CECILE study was funded by Fondation de France, Institut National du Cancer (INCa), Ligue Nationale contre le Cancer, Ligue contre le Cancer Grand Ouest, Agence Nationale de Sécurité Sanitaire (ANSES), Agence Nationale de la Recherche (ANR). The CGPS study was supported by the Chief Physician Johan Boserup and Lise Boserup Fund, the Danish Medical Research Council and Herlev Hospital. The CNIO-BCS study was supported by the Instituto de Salud Carlos III, the Red Temática de Investigación Cooperativa en Cáncer and grants from the Asociación Española Contra el Cáncer and the Fondo de Investigación Sanitario (PI11/00923 and PI12/00070). The CTS study was initially supported by the California Breast Cancer Act of 1993 and the California Breast Cancer Research Fund (contract 97-10500) and is currently funded through the NIH (R01 CA77398). Collection of cancer incidence data (GLOBOCAN 2012) was supported by the California Department of Public Health as part of the statewide cancer reporting program mandated by California Health and Safety Code Sect. 103885. HAC received support from the Lon V Smith Foundation (LVS39420). The ESTHER study was supported by a grant from the Baden Württemberg Ministry of Science, Research and Arts. Additional cases were recruited in the context of the VERDI study, which was supported by a grant from the German Cancer Aid (Deutsche Krebshilfe). The GCHBOC study was supported by the German Cancer Aid (grant no 110837, coordinator: Rita K. Schmutzler). The GENICA study was funded by the Federal Ministry of Education and Research (BMBF) Germany grants 01KW9975/5, 01KW9976/8, 01KW9977/0 and 01KW0114, the Robert Bosch Foundation, Stuttgart, DKFZ, Heidelberg, the Institute for Prevention and Occupational Medicine of the German Social Accident Insurance, Institute of the Ruhr University Bochum (IPA), Bochum, as well as the Department of Internal Medicine, Evangelische Kliniken Bonn gGmbH, Johanniter Krankenhaus, Bonn, Germany. The HEBCS study was financially supported by the Helsinki University Central Hospital Research Fund, Academy of Finland (266528), the Finnish Cancer Society, the Nordic Cancer Union and the Sigrid Juselius Foundation. The HMBCS study was supported by a grant from the Friends of Hannover Medical School and by the Rudolf Bartling Foundation. The KBCP study was financially supported by the special Government Funding (EVO) of Kuopio University Hospital grants, Cancer Fund of North Savo, the Finnish Cancer Organizations, and by the strategic funding of the University of Eastern Finland. The LMBC study was supported by the 'Stichting tegen Kanker' (232-2008 and 196-2010). The MARIE study was supported by the Deutsche Krebshilfe e.V. (70-2892-BR I, 106332, 108253, 108419), the Hamburg Cancer Society, DKFZ and the Federal Ministry of Education and Research (BMBF) Germany (01KH0402). The MBCSG study was supported by grants from the Italian Association for Cancer Research (AIRC) and by funds from the Italian citizens who allocated the 5/1000 share of their tax payment in support of the Fondazione IRCCS Istituto Nazionale Tumori, according to Italian laws (INT-Institutional strategic projects " $\left.5 \times 1000^{\prime \prime}\right)$. The MCBCS study was supported by the NIH grants CA128978, CA116167, CA176785 and NIH Specialized Program of
Research Excellence (SPORE) in Breast Cancer (CA116201), and the Breast Cancer Research Foundation and a generous gift from the David F. and Margaret T. Grohne Family Foundation and the Ting Tsung and Wei Fong Chao Foundation. The MCCS cohort recruitment was funded by VicHealth and Cancer Council Victoria. This study was further supported by Australian NHMRC grants 209057, 251553 and 504711 and by infrastructure provided by Cancer Council Victoria. Cases and their vital status were ascertained through the Victorian Cancer Registry (VCR) and the Australian Institute of Health and Welfare (AIHW), including the National Death Index. The MEC study was support by NIH grants CA63464, CA54281, CA098758 and CA132839. The work of MTLGEBCS was supported by the Quebec Breast Cancer Foundation, the Canadian Institutes of Health Research (CIHR) for the "CIHR Team in Familial Risks of Breast Cancer" program-grant \# CRN-87521 and the Ministry of Economic Development, Innovation and Export Trade-grant \# PSRSIIRI-701. The NBCS study has received funding from the K.G. Jebsen Centre for Breast Cancer Research, the Research Council of Norway grant 193387/V50 (to A-L Børresen-Dale and V.N. Kristensen) and grant 193387/H10 (to A-L Børresen-Dale and V.N. Kristensen), South Eastern Norway Health Authority (grant 39346 to A-L Børresen-Dale) and the Norwegian Cancer Society (to A-L Børresen-Dale and V.N. Kristensen). The NBHS study was supported by NIH grant R01CA100374. Biological sample preparation was conducted the Survey and Biospecimen Shared Resource, which is supported by P30 CA68485. The OBCS study was supported by research grants from the Finnish Cancer Foundation, the Academy of Finland (grant number 250083, 122715 and Center of Excellence grant number 251314), the Finnish Cancer Foundation, the Sigrid Juselius Foundation, the University of Oulu, the University of Oulu Support Foundation and the special Governmental EVO funds for Oulu University Hospital-based research activities. The OFBCR study was supported by grant UM1 CA164920 from the National Cancer Institute (USA). The PBCS study was funded by Intramural Research Funds of the National Cancer Institute, Department of Health and Human Services, USA. The SASBAC study was supported by funding from the Agency for Science, Technology and Research of Singapore (A*STAR), the US National Institute of Health and the Susan G. Komen Breast Cancer Foundation. The SBCS study was supported by Yorkshire Cancer Research S295, S299, S305PA and Sheffield Experimental Cancer Medicine Centre. The SEARCH study was funded by a programme grant from Cancer Research UK (C490/ A10124) and supported by the UK National Institute for Health Research Biomedical Research Centre at the University of Cambridge. The SKKDKFZS study was supported by the DKFZ. The SZBCS study was supported by Polish State Committee for Scientific Research Grant PBZ_KBN_122/P05/2004. The TNBCC study was supported by: a Specialized Program of Research Excellence (SPORE) in Breast Cancer (CA116201), a grant from the Breast Cancer Research Foundation, a generous gift from the David F. and Margaret T. Grohne Family Foundation, the Stefanie Spielman Breast Cancer fund and the OSU Comprehensive Cancer Center, the Hellenic Cooperative Oncology Group research grant (HR R_BG/04) and the Greek General Secretary for Research and Technology (GSRT) Program, Research Excellence II, the European Union (European Social Fund-ESF), and Greek national funds through the Operational Program "Education and Lifelong Learning" of the National Strategic Reference Framework (NSRF)-ARISTEIA. The UKBGS study was funded by Breast Cancer Now and the Institute of Cancer Research (ICR), London. ICR acknowledged NHS funding to the NIHR Biomedical Research Centre. The kConFab study was supported by a grant from the National Breast Cancer Foundation, and previously by the National Health and Medical Research Council (NHMRC), the Queensland Cancer Fund, the Cancer Councils of New South Wales, Victoria, Tasmania and South Australia, and the Cancer Foundation of Western Australia. Financial support for the 
AOCS was provided by the United States Army Medical Research and Materiel Command (DAMD17-01-1-0729), Cancer Council Victoria, Queensland Cancer Fund, Cancer Council New South Wales, Cancer Council South Australia, the Cancer Foundation of Western Australia, Cancer Council Tasmania and the National Health and Medical Research Council of Australia (NHMRC; 400413, 400281, 199600). The pKARMA study was supported by Märit and Hans Rausings Initiative Against Breast Cancer.

Open Access This article is distributed under the terms of the Creative Commons Attribution 4.0 International License (http://crea tivecommons.org/licenses/by/4.0/), which permits unrestricted use, distribution, and reproduction in any medium, provided you give appropriate credit to the original author(s) and the source, provide a link to the Creative Commons license, and indicate if changes were made.

\section{References}

Abecasis GR, Auton A, Brooks LD, DePristo MA, Durbin RM, Handsaker RE, Kang HM, Marth GT, McVean GA (2012) An integrated map of genetic variation from 1,092 human genomes. Nature 491:56-65. doi:10.1038/nature11632

Aliper AM, Frieden-Korovkina VP, Buzdin A, Roumiantsev SA, Zhavoronkov A (2014) Interactome analysis of myeloid-derived suppressor cells in murine models of colon and breast cancer. Oncotarget 5:11345-11353

Bai L, Deng X, Li Q, Wang M, An W, Deli A, Gao Z, Xie Y, Dai Y, Cong YS (2012) Down-regulation of the cavin family proteins in breast cancer. J Cell Biochem 113:322-328. doi:10.1002/jcb.23358

Barrett JC, Fry B, Maller J, Daly MJ (2005) Haploview: analysis and visualization of $\mathrm{LD}$ and haplotype maps. Bioinformatics 21:263-265. doi:10.1093/bioinformatics/bth457

Barrett JC, Hansoul S, Nicolae DL, Cho JH, Duerr RH, Rioux JD, Brant SR, Silverberg MS, Taylor KD, Barmada MM, Bitton A, Dassopoulos T, Datta LW, Green T, Griffiths AM, Kistner EO, Murtha MT, Regueiro MD, Rotter JI, Schumm LP, Steinhart AH, Targan SR, Xavier RJ, Libioulle C, Sandor C, Lathrop M, Belaiche J, Dewit O, Gut I, Heath S, Laukens D, Mni M, Rutgeerts P, Van Gossum A, Zelenika D, Franchimont D, Hugot JP, de Vos M, Vermeire S, Louis E, Cardon LR, Anderson CA, Drummond H, Nimmo E, Ahmad T, Prescott NJ, Onnie CM, Fisher SA, Marchini J, Ghori J, Bumpstead S, Gwilliam R, Tremelling M, Deloukas P, Mansfield J, Jewell D, Satsangi J, Mathew CG, Parkes M, Georges M, Daly MJ (2008) Genomewide association defines more than 30 distinct susceptibility loci for Crohn's disease. Nat Genet 40:955-962. doi:10.1038/ng.175

Bates GJ, Fox SB, Han C, Leek RD, Garcia JF, Harris AL, Banham AH (2006) Quantification of regulatory $\mathrm{T}$ cells enables the identification of high-risk breast cancer patients and those at risk of late relapse. J Clin Oncol 24:5373-5380. doi:10.1200/jco. 2006.05.9584

Biernacka JM, Jenkins GD, Wang L, Moyer AM, Fridley BL (2012) Use of the gamma method for self-contained gene-set analysis of SNP data. Eur J Hum Genet 20:565-571. doi:10.1038/ejhg.2011. 236

Breast Cancer Association Consortium. http://www.apps.ccge. medschl.cam.ac.uk/consortia/bcac/. Accessed 19 May 2015

Chadda R, Mayor S (2008) PTRF triggers a cave in. Cell 132:23-24. doi:10.1016/j.cell.2007.12.021

Chang WC, Li CH, Huang SC, Chang DY, Chou LY, Sheu BC (2010) Clinical significance of regulatory $\mathrm{T}$ cells and CD8+ effector populations in patients with human endometrial carcinoma. Cancer 116:5777-5788. doi:10.1002/cncr.25371

Chen B, Wilkening S, Drechsel M, Hemminki K (2009) SNP_tools: a compact tool package for analysis and conversion of genotype data for MS-Excel. BMC Res Note 2:214. doi:10.1186/17560500-2-214

Cheng F, Wang HW, Cuenca A, Huang M, Ghansah T, Brayer J, Kerr WG, Takeda K, Akira S, Schoenberger SP, Yu H, Jove R, Sotomayor EM (2003) A critical role for Stat3 signaling in immune tolerance. Immunity 19:425-436

Cheng P, Corzo CA, Luetteke N, Yu B, Nagaraj S, Bui MM, Ortiz M, Nacken W, Sorg C, Vogl T, Roth J, Gabrilovich DI (2008) Inhibition of dendritic cell differentiation and accumulation of myeloid-derived suppressor cells in cancer is regulated by S100A9 protein. J Exp Med 205:2235-2249. doi:10.1084/jem. 20080132

DeNardo DG, Coussens LM (2007) Inflammation and breast cancer. Balancing immune response: crosstalk between adaptive and innate immune cells during breast cancer progression. Breast Cancer Res 9:212. doi: $10.1186 / \mathrm{bcr} 1746$

DeNardo DG, Andreu P, Coussens LM (2010) Interactions between lymphocytes and myeloid cells regulate pro- versus anti-tumor immunity. Cancer Metastasis Rev 29:309-316. doi:10.1007/ s10555-010-9223-6

Driessens G, Kline J, Gajewski TF (2009) Costimulatory and coinhibitory receptors in anti-tumor immunity. Immunol Rev 229:126-144. doi:10.1111/j.1600-065X.2009.00771.x

Franke A, Balschun T, Karlsen TH, Hedderich J, May S, Lu T, Schuldt D, Nikolaus S, Rosenstiel P, Krawczak M, Schreiber S (2008) Replication of signals from recent studies of Crohn's disease identifies previously unknown disease loci for ulcerative colitis. Nat Genet 40:713-715. doi:10.1038/ng.148

French JD, Ghoussaini M, Edwards SL, Meyer KB, Michailidou K, Ahmed S, Khan S, Maranian MJ, O'Reilly M, Hillman KM, Betts JA, Carroll T, Bailey PJ, Dicks E, Beesley J, Tyrer J, Maia AT, Beck A, Knoblauch NW, Chen C, Kraft P, Barnes D, Gonzalez-Neira A, Alonso MR, Herrero D, Tessier DC, Vincent D, Bacot F, Luccarini C, Baynes C, Conroy D, Dennis J, Bolla MK, Wang Q, Hopper JL, Southey MC, Schmidt MK, Broeks A, Verhoef S, Cornelissen S, Muir K, Lophatananon A, StewartBrown S, Siriwanarangsan P, Fasching PA, Loehberg CR, Ekici AB, Beckmann MW, Peto J, dos Santos Silva I, Johnson N, Aitken Z, Sawyer EJ, Tomlinson I, Kerin MJ, Miller N, Marme F, Schneeweiss A, Sohn C, Burwinkel B, Guenel P, Truong T, Laurent-Puig P, Menegaux F, Bojesen SE, Nordestgaard BG, Nielsen SF, Flyger H, Milne RL, Zamora MP, Arias Perez JI, Benitez J, Anton-Culver H, Brenner H, Muller H, Arndt V, Stegmaier C, Meindl A, Lichtner P, Schmutzler RK, Engel C, Brauch H, Hamann U, Justenhoven C, Aaltonen K, Heikkila P, Aittomaki K, Blomqvist C, Matsuo K, Ito H, Iwata H, Sueta A, Bogdanova NV, Antonenkova NN, Dork T, Lindblom A, Margolin S, Mannermaa A, Kataja V, Kosma VM et al (2013) Functional variants at the $11 \mathrm{q} 13$ risk locus for breast cancer regulate cyclin D1 expression through long-range enhancers. Am J Hum Genet 92:489-503. doi:10.1016/j.ajhg.2013.01.002

Gabrilovich DI, Nagaraj S (2009) Myeloid-derived suppressor cells as regulators of the immune system. Nat Rev Immunol 9:162-174. doi:10.1038/nri2506

Gad E, Rastetter L, Slota M, Koehnlein M, Treuting PM, Dang Y, Stanton S, Disis ML (2014) Natural history of tumor growth and immune modulation in common spontaneous murine mammary tumor models. Breast Cancer Res Treat 148:501-510. doi:10. 1007/s10549-014-3199-9

GLOBOCAN 2012: Estimated Cancer Incidence, Mortality and Prevalence Worldwide in 2012. International Agency for 
Research on Cancer. http://www.globocan.iarc.fr/Default.aspx. Accessed 9 Apr 2015

Hanahan D, Weinberg RA (2011) Hallmarks of cancer: the next generation. Cell 144:646-674. doi:10.1016/j.cell.2011.02.013

Howie BN, Donnelly P, Marchini J (2009) A flexible and accurate genotype imputation method for the next generation of genomewide association studies. PLoS Genet 5:e1000529. doi:10.1371/ journal.pgen.1000529

Howie B, Fuchsberger C, Stephens M, Marchini J, Abecasis GR (2012) Fast and accurate genotype imputation in genome-wide association studies through pre-phasing. Nat Genet 44:955-959. doi:10.1038/ng.2354

International HapMap Project. http://www.hapmap.org/. Accessed 26 Mar 2015

Jakkula E, Leppa V, Sulonen AM, Varilo T, Kallio S, Kemppinen A, Purcell S, Koivisto K, Tienari P, Sumelahti ML, Elovaara I, Pirttila T, Reunanen M, Aromaa A, Oturai AB, Sondergaard HB, Harbo HF, Mero IL, Gabriel SB, Mirel DB, Hauser SL, Kappos L, Polman C, De Jager PL, Hafler DA, Daly MJ, Palotie A, Saarela J, Peltonen L (2010) Genome-wide association study in a high-risk isolate for multiple sclerosis reveals associated variants in STAT3 gene. Am J Hum Genet 86:285-291. doi:10.1016/j. ajhg.2010.01.017

Jostins L, Ripke S, Weersma RK, Duerr RH, McGovern DP, Hui KY, Lee JC, Schumm LP, Sharma Y, Anderson CA, Essers J, Mitrovic M, Ning K, Cleynen I, Theatre E, Spain SL, Raychaudhuri S, Goyette P, Wei Z, Abraham C, Achkar JP, Ahmad T, Amininejad L, Ananthakrishnan AN, Andersen V, Andrews JM, Baidoo L, Balschun T, Bampton PA, Bitton A, Boucher G, Brand S, Buning C, Cohain A, Cichon S, D'Amato M, De Jong D, Devaney KL, Dubinsky M, Edwards C, Ellinghaus D, Ferguson LR, Franchimont D, Fransen K, Gearry R, Georges M, Gieger C, Glas J, Haritunians T, Hart A, Hawkey C, Hedl M, Hu X, Karlsen TH, Kupcinskas L, Kugathasan S, Latiano A, Laukens D, Lawrance IC, Lees CW, Louis E, Mahy G, Mansfield J, Morgan AR, Mowat C, Newman W, Palmieri O, Ponsioen CY, Potocnik U, Prescott NJ, Regueiro M, Rotter JI, Russell RK, Sanderson JD, Sans M, Satsangi J, Schreiber S, Simms LA, Sventoraityte J, Targan SR, Taylor KD, Tremelling M, Verspaget HW, De Vos M, Wijmenga C, Wilson DC, Winkelmann J, Xavier RJ, Zeissig S, Zhang B, Zhang CK, Zhao H, Silverberg MS, Annese V, Hakonarson H, Brant SR, RadfordSmith G, Mathew CG, Rioux JD, Schadt EE et al (2012) Hostmicrobe interactions have shaped the genetic architecture of inflammatory bowel disease. Nature 491:119-124. doi:10.1038/ nature 11582

Kim ST, Jeong H, Woo OH, Seo JH, Kim A, Lee ES, Shin SW, Kim YH, Kim JS, Park KH (2013) Tumor-infiltrating lymphocytes, tumor characteristics, and recurrence in patients with early breast cancer. Am J Clin Oncol 36:224-231. doi:10.1097/COC. 0b013e3182467d 90

Kortylewski M, Kujawski M, Wang T, Wei S, Zhang S, PilonThomas S, Niu G, Kay H, Mule J, Kerr WG, Jove R, Pardoll D, $\mathrm{Yu} \mathrm{H}$ (2005) Inhibiting Stat3 signaling in the hematopoietic system elicits multicomponent antitumor immunity. Nat Med 11:1314-1321. doi:10.1038/nm1325

Kortylewski M, Xin H, Kujawski M, Lee H, Liu Y, Harris T, Drake C, Pardoll D, Yu H (2009) Regulation of the IL-23 and IL-12 balance by Stat3 signaling in the tumor microenvironment. Cancer Cell 15:114-123. doi:10.1016/j.ccr.2008.12.018

Krieg C, Boyman O (2009) The role of chemokines in cancer immune surveillance by the adaptive immune system. Semin Cancer Biol 19:76-83. doi:10.1016/j.semcancer.2008.10.011

Kujawski M, Kortylewski M, Lee H, Herrmann A, Kay H, Yu H (2008) Stat 3 mediates myeloid cell-dependent tumor angiogenesis in mice. J Clin Invest 118:3367-3377. doi:10.1172/jci35213
Lindau D, Gielen P, Kroesen M, Wesseling P, Adema GJ (2013) The immunosuppressive tumour network: myeloid-derived suppressor cells, regulatory $\mathrm{T}$ cells and natural killer T cells. Immunology 138:105-115. doi:10.1111/imm.12036

Liu F, Li Y, Ren M, Zhang X, Guo X, Lang R, Gu F, Fu L (2012a) Peritumoral FOXP3(+) regulatory $\mathrm{T}$ cell is sensitive to chemotherapy while intratumoral FOXP3(+) regulatory $\mathrm{T}$ cell is prognostic predictor of breast cancer patients. Breast Cancer Res Treat 135:459-467. doi:10.1007/s10549-012-2132-3

Liu LY, Chang LY, Kuo WH, Hwa HL, Lin YS, Huang SF, Chen CN, Chang KJ, Hsieh FJ (2012b) Major Functional Transcriptome of an Inferred Center Regulator of an ER(-) Breast Cancer Model System. Cancer Inform 11:87-111. doi:10.4137/cin.s8633

Long JC, Williams RC, Urbanek M (1995) An E-M algorithm and testing strategy for multiple-locus haplotypes. Am J Hum Genet 56:799-810

Matsumura Y, Kobayashi T, Ichiyama K, Yoshida R, Hashimoto M, Takimoto T, Tanaka K, Chinen T, Shichita T, Wyss-Coray T, Sato K, Yoshimura A (2007) Selective expansion of foxp3positive regulatory $\mathrm{T}$ cells and immunosuppression by suppressors of cytokine signaling 3-deficient dendritic cells. J Immunol 179:2170-2179

Michailidou K, Hall P, Gonzalez-Neira A, Ghoussaini M, Dennis J, Milne RL, Schmidt MK, Chang-Claude J, Bojesen SE, Bolla MK, Wang Q, Dicks E, Lee A, Turnbull C, Rahman N, Fletcher O, Peto J, Gibson L, Dos Santos Silva I, Nevanlinna H, Muranen TA, Aittomaki K, Blomqvist C, Czene K, Irwanto A, Liu J, Waisfisz Q, Meijers-Heijboer H, Adank M, van der Luijt RB, Hein R, Dahmen N, Beckman L, Meindl A, Schmutzler RK, Muller-Myhsok B, Lichtner P, Hopper JL, Southey MC, Makalic E, Schmidt DF, Uitterlinden AG, Hofman A, Hunter DJ, Chanock SJ, Vincent D, Bacot F, Tessier DC, Canisius S, Wessels LF, Haiman CA, Shah M, Luben R, Brown J, Luccarini C, Schoof N, Humphreys K, Li J, Nordestgaard BG, Nielsen SF, Flyger $\mathrm{H}$, Couch FJ, Wang $\mathrm{X}$, Vachon $\mathrm{C}$, Stevens $\mathrm{KN}$, Lambrechts D, Moisse M, Paridaens R, Christiaens MR, Rudolph A, Nickels S, Flesch-Janys D, Johnson N, Aitken Z, Aaltonen K, Heikkinen T, Broeks A, Veer LJ, van der Schoot CE, Guenel P, Truong T, Laurent-Puig P, Menegaux F, Marme F, Schneeweiss A, Sohn C, Burwinkel B, Zamora MP, Perez JI, Pita G, Alonso MR, Cox A, Brock IW, Cross SS, Reed MW, Sawyer EJ, Tomlinson I, Kerin MJ, Miller N, Henderson BE et al (2013) Large-scale genotyping identifies 41 new loci associated with breast cancer risk. Nat Genet 45:353-361. doi:10.1038/ng. 2563 (361e1-2)

Michailidou K, Beesley J, Lindstrom S, Canisius S, Dennis J, Lush MJ, Maranian MJ, Bolla MK, Wang Q, Shah M, Perkins BJ, Czene K, Eriksson M, Darabi H, Brand JS, Bojesen SE, Nordestgaard BG, Flyger H, Nielsen SF, Rahman N, Turnbull C, Fletcher O, Peto J, Gibson L, Dos-Santos-Silva I, ChangClaude J, Flesch-Janys D, Rudolph A, Eilber U, Behrens S, Nevanlinna H, Muranen TA, Aittomaki K, Blomqvist C, Khan S, Aaltonen K, Ahsan H, Kibriya MG, Whittemore AS, John EM, Malone KE, Gammon MD, Santella RM, Ursin G, Makalic E, Schmidt DF, Casey G, Hunter DJ, Gapstur SM, Gaudet MM, Diver WR, Haiman CA, Schumacher F, Henderson BE, Le Marchand L, Berg CD, Chanock SJ, Figueroa J, Hoover RN, Lambrechts D, Neven P, Wildiers H, van Limbergen E, Schmidt MK, Broeks A, Verhoef S, Cornelissen S, Couch FJ, Olson JE, Hallberg E, Vachon C, Waisfisz Q, Meijers-Heijboer H, Adank MA, van der Luijt RB, Li J, Liu J, Humphreys K, Kang D, Choi JY, Park SK, Yoo KY, Matsuo K, Ito H, Iwata H, Tajima K, Guenel P, Truong T, Mulot C, Sanchez M, Burwinkel B, Marme F, Surowy H, Sohn C, Wu AH, Tseng CC, Van Den Berg D, Stram DO, Gonzalez-Neira A, Benitez J et al (2015) Genomewide association analysis of more than 120,000 individuals 
identifies 15 new susceptibility loci for breast cancer. Nat Genet 47:373-380. doi:10.1038/ng.3242

Michel S, Benner A, Tariverdian M, Wentzensen N, Hoefler P, Pommerencke T, Grabe N, von Knebel Doeberitz M, Kloor M (2008) High density of FOXP3-positive T cells infiltrating colorectal cancers with microsatellite instability. Br J Cancer 99:1867-1873. doi:10.1038/sj.bjc.6604756

Mills KH (2004) Regulatory T cells: friend or foe in immunity to infection? Nat Rev Immunol 4:841-855. doi:10.1038/nri1485

Okada Y, Terao C, Ikari K, Kochi Y, Ohmura K, Suzuki A, Kawaguchi T, Stahl EA, Kurreeman FA, Nishida N, Ohmiya H, Myouzen K, Takahashi M, Sawada T, Nishioka Y, Yukioka M, Matsubara T, Wakitani S, Teshima R, Tohma S, Takasugi K, Shimada K, Murasawa A, Honjo S, Matsuo K, Tanaka H, Tajima K, Suzuki T, Iwamoto T, Kawamura Y, Tanii H, Okazaki Y, Sasaki T, Gregersen PK, Padyukov L, Worthington J, Siminovitch KA, Lathrop M, Taniguchi A, Takahashi A, Tokunaga K, Kubo M, Nakamura Y, Kamatani N, Mimori T, Plenge RM, Yamanaka H, Momohara S, Yamada R, Matsuda F, Yamamoto $\mathrm{K}$ (2012) Meta-analysis identifies nine new loci associated with rheumatoid arthritis in the Japanese population. Nat Genet 44:511-516. doi:10.1038/ng.2231

Okada Y, Wu D, Trynka G, Raj T, Terao C, Ikari K, Kochi Y, Ohmura K, Suzuki A, Yoshida S, Graham RR, Manoharan A, Ortmann W, Bhangale T, Denny JC, Carroll RJ, Eyler AE, Greenberg JD, Kremer JM, Pappas DA, Jiang L, Yin J, Ye L, Su DF, Yang J, Xie G, Keystone E, Westra HJ, Esko T, Metspalu A, Zhou X, Gupta N, Mirel D, Stahl EA, Diogo D, Cui J, Liao K, Guo MH, Myouzen K, Kawaguchi T, Coenen MJ, van Riel PL, van de Laar MA, Guchelaar HJ, Huizinga TW, Dieude P, Mariette X, Bridges SL Jr, Zhernakova A, Toes RE, Tak PP, Miceli-Richard C, Bang SY, Lee HS, Martin J, Gonzalez-Gay MA, Rodriguez-Rodriguez L, Rantapaa-Dahlqvist S, Arlestig L, Choi HK, Kamatani Y, Galan P, Lathrop M, Eyre S, Bowes J, Barton A, de Vries N, Moreland LW, Criswell LA, Karlson EW, Taniguchi A, Yamada R, Kubo M, Liu JS, Bae SC, Worthington J, Padyukov L, Klareskog L, Gregersen PK, Raychaudhuri S, Stranger BE, De Jager PL, Franke L, Visscher PM, Brown MA, Yamanaka H, Mimori T, Takahashi A, Xu H, Behrens TW, Siminovitch KA, Momohara S, Matsuda F, Yamamoto K, Plenge RM (2014) Genetics of rheumatoid arthritis contributes to biology and drug discovery. Nature 506:376-381. doi:10.1038/ nature 12873

Ostrand-Rosenberg S (2008) Immune surveillance: a balance between protumor and antitumor immunity. Curr Opin Genet Dev 18:11-18. doi:10.1016/j.gde.2007.12.007

Ostrand-Rosenberg S, Sinha P (2009) Myeloid-derived suppressor cells: linking inflammation and cancer. J Immunol 182:44994506. doi:10.4049/jimmunol.0802740

Parker DC (1993) T cell-dependent B cell activation. Annu Rev Immunol 11:331-360. doi:10.1146/annurev.iy.11.040193.001555

Patsopoulos NA, Esposito F, Reischl J, Lehr S, Bauer D, Heubach J, Sandbrink R, Pohl C, Edan G, Kappos L, Miller D, Montalban J, Polman CH, Freedman MS, Hartung HP, Arnason BG, Comi G, Cook S, Filippi M, Goodin DS, Jeffery D, O'Connor P, Ebers GC, Langdon D, Reder AT, Traboulsee A, Zipp F, Schimrigk S, Hillert J, Bahlo M, Booth DR, Broadley S, Brown MA, Browning BL, Browning SR, Butzkueven $\mathrm{H}$, Carroll WM, Chapman C, Foote SJ, Griffiths L, Kermode AG, Kilpatrick TJ, Lechner-Scott J, Marriott M, Mason D, Moscato P, Heard RN, Pender MP, Perreau VM, Perera D, Rubio JP, Scott RJ, Slee M, Stankovich J, Stewart GJ, Taylor BV, Tubridy N, Willoughby E, Wiley J, Matthews P, Boneschi FM, Compston A, Haines J, Hauser SL, McCauley J, Ivinson A, Oksenberg JR, PericakVance M, Sawcer SJ, De Jager PL, Hafler DA, de Bakker PI (2011) Genome-wide meta-analysis identifies novel multiple sclerosis susceptibility loci. Ann Neurol 70:897-912. doi:10. 1002/ana.22609

Poschke I, Mougiakakos D, Kiessling R (2011) Camouflage and sabotage: tumor escape from the immune system. Cancer Immunol Immunother 60:1161-1171. doi:10.1007/s00262-0111012-8

Pruim RJ, Welch RP, Sanna S, Teslovich TM, Chines PS, Gliedt TP, Boehnke M, Abecasis GR, Willer CJ (2010) LocusZoom: regional visualization of genome-wide association scan results. Bioinformatics 26:2336-2337. doi:10.1093/bioinformatics/ btq 419

Purcell S, Neale B, Todd-Brown K, Thomas L, Ferreira MA, Bender D, Maller J, Sklar P, de Bakker PI, Daly MJ, Sham PC (2007) PLINK: a tool set for whole-genome association and populationbased linkage analyses. Am J Hum Genet 81:559-575. doi:10. $1086 / 519795$

Reisfeld RA (2013) The tumor microenvironment: a target for combination therapy of breast cancer. Crit Rev Oncog $18: 115-133$

Rhie SK, Coetzee SG, Noushmehr H, Yan C, Kim JM, Haiman CA, Coetzee GA (2013) Comprehensive functional annotation of seventy-one breast cancer risk Loci. PLoS One 8:e63925. doi:10. 1371/journal.pone.0063925

Sakaguchi S, Vignali DA, Rudensky AY, Niec RE, Waldmann H (2013) The plasticity and stability of regulatory T cells. Nat Rev Immunol 13:461-467. doi:10.1038/nri3464

Sawcer S, Hellenthal G, Pirinen M, Spencer CC, Patsopoulos NA, Moutsianas L, Dilthey A, Su Z, Freeman C, Hunt SE, Edkins S, Gray E, Booth DR, Potter SC, Goris A, Band G, Oturai AB, Strange A, Saarela J, Bellenguez C, Fontaine B, Gillman M, Hemmer B, Gwilliam R, Zipp F, Jayakumar A, Martin R, Leslie S, Hawkins S, Giannoulatou E, D'Alfonso S, Blackburn H, Martinelli Boneschi F, Liddle J, Harbo HF, Perez ML, Spurkland A, Waller MJ, Mycko MP, Ricketts M, Comabella M, Hammond N, Kockum I, McCann OT, Ban M, Whittaker P, Kemppinen A, Weston P, Hawkins C, Widaa S, Zajicek J, Dronov S, Robertson N, Bumpstead SJ, Barcellos LF, Ravindrarajah R, Abraham R, Alfredsson L, Ardlie K, Aubin C, Baker A, Baker K, Baranzini SE, Bergamaschi L, Bergamaschi R, Bernstein A, Berthele A, Boggild M, Bradfield JP, Brassat D, Broadley SA, Buck D, Butzkueven H, Capra R, Carroll WM, Cavalla P, Celius EG, Cepok S, Chiavacci R, Clerget-Darpoux F, Clysters K, Comi G, Cossburn M, Cournu-Rebeix I, Cox MB, Cozen W, Cree BA, Cross AH, Cusi D, Daly MJ, Davis E, de Bakker PI, Debouverie M, D’Hooghe MB, Dixon K, Dobosi R, Dubois B, Ellinghaus D, Elovaara I, Esposito F et al (2011) Genetic risk and a primary role for cell-mediated immune mechanisms in multiple sclerosis. Nature 476:214-219. doi:10.1038/nature10251

Serafini P, Carbley R, Noonan KA, Tan G, Bronte V, Borrello I (2004) High-dose granulocyte-macrophage colony-stimulating factor-producing vaccines impair the immune response through the recruitment of myeloid suppressor cells. Cancer Res 64:6337-6343. doi:10.1158/0008-5472.can-04-0757

Sica A, Larghi P, Mancino A, Rubino L, Porta C, Totaro MG, Rimoldi M, Biswas SK, Allavena P, Mantovani A (2008) Macrophage polarization in tumour progression. Semin Cancer Biol 18:349-355. doi:10.1016/j.semcancer.2008.03.004

The Cancer Genome Atlas. http://www.cancergenome.nih.gov/. Accessed 1 Apr 2015

The Genotype-Tissue Expression Portal. http://www.gtexportal.org/ home/. Accessed 19 Oct 2015

UCSC Genome Browser. https://www.genome-euro.ucsc.edu/cgi-bin/ hgGateway?redirect=manual\&source=genome.ucsc.edu. Accessed 19 Oct 2015

Ward LD, Kellis M (2012) HaploReg: a resource for exploring chromatin states, conservation, and regulatory motif alterations 
within sets of genetically linked variants. Nucleic Acid Res 40:D930-D934. doi:10.1093/nar/gkr917

Watanabe Y, Kinoshita A, Yamada T, Ohta T, Kishino T, Matsumoto N, Ishikawa M, Niikawa N, Yoshiura K (2002) A catalog of 106 single-nucleotide polymorphisms (SNPs) and 11 other types of variations in genes for transforming growth factor-betal (TGFbeta1) and its signaling pathway. J Hum Genet 47:478-483. doi:10.1007/s100380200069

Wilczynski JR, Duechler M (2010) How do tumors actively escape from host immunosurveillance? Arch Immunol Ther Exp (Warsz) 58:435-448. doi:10.1007/s00005-010-0102-1

Yamazaki K, Umeno J, Takahashi A, Hirano A, Johnson TA, Kumasaka N, Morizono T, Hosono N, Kawaguchi T, Takazoe M, Yamada T, Suzuki Y, Tanaka H, Motoya S, Hosokawa M, Arimura Y, Shinomura Y, Matsui T, Matsumoto T, Iida M, Tsunoda T, Nakamura Y, Kamatani N, Kubo M (2013) A genome-wide association study identifies 2 susceptibility Loci for Crohn's disease in a Japanese population. Gastroenterology 144:781-788. doi:10.1053/j.gastro.2012.12.021

Yang L, Pang Y, Moses HL (2010) TGF-beta and immune cells: an important regulatory axis in the tumor microenvironment and progression. Trends Immunol 31:220-227. doi:10.1016/j.it.2010. 04.002

Yu H, Pardoll D, Jove R (2009) STATs in cancer inflammation and immunity: a leading role for STAT3. Nat Rev Cancer 9:798-809. doi:10.1038/nrc2734

Zitvogel L, Tesniere A, Kroemer G (2006) Cancer despite immunosurveillance: immunoselection and immunosubversion. Nat Rev Immunol 6:715-727. doi:10.1038/nri1936

Zou W (2005) Immunosuppressive networks in the tumour environment and their therapeutic relevance. Nat Rev Cancer 5:263-274. doi:10.1038/nrc1586 